\title{
Cariporide and other new and powerful NHE1 inhibitors as potentially selective anticancer drugs - an integral molecular/biochemical/ metabolic/clinical approach after one hundred years of cancer research
}

\author{
Salvador Harguindey ${ }^{1 *+}$, Jose Luis Arranz ${ }^{1}$, Julian David Polo Orozco ${ }^{1}$, Cyril Rauch², Stefano Fais ${ }^{3,4}$, \\ Rosa Angela Cardone ${ }^{5}$ and Stephan J Reshkin ${ }^{5+}$
}

\begin{abstract}
In recent years an increasing number of publications have emphasized the growing importance of hydrogen ion dynamics in modern cancer research, from etiopathogenesis and treatment. A proton $\left[\mathrm{H}^{+}\right]$-related mechanism underlying the initiation and progression of the neoplastic process has been recently described by different research groups as a new paradigm in which all cancer cells and tissues, regardless of their origin and genetic background, have a pivotal energetic and homeostatic disturbance of their metabolism that is completely different from all normal tissues: an aberrant regulation of hydrogen ion dynamics leading to a reversal of the $\mathrm{pH}$ gradient in cancer cells and tissues ( $\uparrow \mathrm{pH}_{\mathrm{i}} / \mathrm{s}$ $\downarrow \mathrm{pH}_{\mathrm{e}}$, or "proton reversal"). Tumor cells survive their hostile microenvironment due to membrane-bound proton pumps and transporters, and their main defensive strategy is to never allow internal acidification because that could lead to their death through apoptosis. In this context, one of the primary and best studied regulators of both $\mathrm{pH}_{\mathrm{i}}$ and $\mathrm{pH}_{\mathrm{e}}$ in tumors is the $\mathrm{Na}^{+} / \mathrm{H}^{+}$exchanger isoform 1 (NHE1). An elevated NHE1 activity can be correlated with both an increase in cell pH and a decrease in the extracellular pH of tumors, and such proton reversal is associated with the origin, local growth, activation and further progression of the metastatic process. Consequently, NHE1 pharmaceutical inhibition by new and potent NHE1 inhibitors represents a potential and highly selective target in anticancer therapy. Cariporide, being one of the better studied specific and powerful NHE1 inhibitors, has proven to be well tolerated by humans in the cardiological context, however some side-effects, mainly related to drug accumulation and cerebrovascular complications were reported. Thus, cariporide could become a new, slightly toxic and effective anticancer agent in different human malignancies.
\end{abstract}

Keywords: pH and cancer, Cancer etiopathogenesis, Proton transporters, Proton transport inhibitors, Cariporide in cancer, NHE1 and cancer, Cancer treatment, Multiple drug resistance, New therapeutic paradigm in cancer

\section{Rationale}

Proton transport and its inhibition as an approach to cancer etiopathogenesis and treatment

The pathological regulation of hydrogen ion dynamics in cancer cells and tissues leads to a reversed hydrogen ion gradient in these cells $\left(\uparrow \mathrm{pH}_{\mathrm{i}} / \downarrow \mathrm{pH}_{\mathrm{e}}\right)$. This results in a very

\footnotetext{
* Correspondence: salvaszh@telefonica.net

${ }^{\dagger}$ Equal contributors

'Instituto de Biología Clínica y Metabolismo (IBCM), Postas 13-01004, Vitoria, Spain Full list of author information is available at the end of the article
}

acidic extracellular microenvironment specific to all malignant tumors [1-5]. Thus, malignant cells have an acid-base balance that is completely different to that observed in normal tissues and that increases with increasing neoplastic state: an extracellular acid microenvironment $\left(\mathrm{pH}_{\mathrm{e}}\right)$ linked to a 'malignant' alkaline intracellular $\mathrm{pH}$ $\left(\mathrm{pH}_{\mathrm{i}}\right)$ [4]. Indeed, tumor cells have alkaline $\mathrm{pH}_{\mathrm{i}}$ values of 7.12-7.7 vs 6.99-7.05 in normal cells while producing acidic $\mathrm{pH}_{\mathrm{e}}$ values of 6.2-6.9 vs 7.3-7.4 in normal cells (Table 1) $[4,6,7]$. This specific and pathological reversal of the $\mathrm{pH}$ gradient in cancer cells and tissues compared to

\section{Biomed Central}


Table $1 \mathrm{pH}_{\mathrm{i}}$ and $\mathrm{pH}_{\mathrm{e}}$ in normal and cancer cells: apoptosis and antiapoptosis

\begin{tabular}{ccc}
\hline & Normal cells & Cancer cells \\
\hline & $\left(\mathrm{pH}_{\mathrm{i}}<\mathrm{pH}_{\mathrm{e}}\right)$ & $\begin{array}{c}\left(\mathrm{pH}_{\mathrm{i}}>\mathrm{pH}_{\mathrm{e}}\right) \\
\text { ("proton gradient reversal”) }\end{array}$ \\
Intracellular $\mathrm{pH}\left(\mathrm{pH}_{\mathrm{i}}\right)$ & $6.99-7.05$ & $\begin{array}{c}7.12-7.7 \\
\text { Extracellular/ }\end{array}$ \\
$\begin{array}{c}\text { interstitial } \mathrm{pH}\left(\mathrm{pH}_{\mathrm{e}}\right) \\
\mathrm{pH}_{\mathrm{i}}<6-6.5\end{array}$ & $7.35-7.45$ & $6.2-6.9$ \\
& & (Therapeutic apoptosis)
\end{tabular}

For further details, see text and refs. $[4,40]$.

normal tissues ("proton reversal") is now considered to be one of the main characteristics defining tumor cells that completely alters their thermodynamic balance and molecular energetics, regardless of their pathology and genetic origins. The induction and/or maintenance of intracellular alkalinization and its subsequent extracellular/interstitial acidosis on intratumoral dynamics have been repeatedly implicated as playing an essential, direct and pivotal role both in cell transformation and growth as well as in the active progression and maintenance of the neoplastic process [8-10]. Moreover, this intracellular alkalosis represents a common final pathway in cell transformation through the stimulation of the $\mathrm{Na}^{+} / \mathrm{H}^{+}$transporter by a myriad of carcinogens of the most varied origins and natures [8-19]. Such a wide array of carcinogens induce cell transformation and an increase in cell $\mathrm{pH}[14,17-24]$.

\section{Factors that increase cell $\mathrm{pH}$ and/or stimulate NHE activity as mediators of high $\mathrm{pH}_{\mathrm{i}}$-mediated carcinogenicity}

Virus (HPV E5, human polioma virus)

Oncogenes and viral proteins (v-mos, Ha-Ras, HPV16 E7)

Gen products (Bcl-2)

p53 deficiency

Chemicals carcinogens (arsenic salts, etc.)

Chronic hypoxia and HIF

Hormones (insulin, somatostatin, growth

hormone, glucocorticoids)

Growth factors (IGF-1, HGH, PDGF, VEGF, EGF, IL-1,

IL-8, TGF- $\beta$, G-CSF,

Angiotensin II, $\mathrm{PGE}_{2}$, diferric transferrin, bombesin)

Such an elevated $\mathrm{pH}_{\mathrm{i}}$ was very early on implicated as a crucial factor and target in neoplastic transformation in response to the overexpression of certain proton transporters as well as the ras and v-mos oncogenes [25,26]. It was observed that oncogene-dependent transformation resulted in an elevated $\mathrm{pH}_{\mathrm{i}}$, increased NHE1 activity and increased glycolysis, although it was not clear from those early experiments if the driving factor was the stimulated
NHE1, an elevation of $\mathrm{pH}_{\mathrm{i}}$ or the increased glycolysis itself. This question was resolved in a study utilizing the inducible expression of an oncogene (HPV16 E7) to dissect the timedependence of the appearance of the three above-mentioned factors [10]. This study demonstrated that the first step in oncogene-dependent transformation of normal cells is the activation of the NHE1 with the subsequent cytosolic alkalinization followed by an increase in glycolysis. Furthermore, it was demonstrated that this alkalinization was the driver of a series of transformation hallmarks such as increased growth rate, substrate-independent growth, growth factor independence and tumor growth $[4,18,27,28]$. Altogether, these data demonstrate that oncogenes utilize NHE1-induced cellular alkalinization to produce the unique cancer specific $\mathrm{pH}$ regulation with the resulting $\mathrm{pH}$ related hallmark phenotypes characteristic of cancer cells. NHE1, by controlling $\mathrm{pH}_{\mathrm{i}}$ and preventing cell acidification plays a key role in cell survival/proliferation and tumour growth. Even from an epidemiological perspective, it was recently shown that low concentrations of arsenic salts in drinking water induce a carcinogenic effect directly related to the onset of different human tumors and that this effect is mediated by the stimulation of NHE1 and the resulting increase in cytosolic $\mathrm{pH}$. These authors concluded that the increase in cell $\mathrm{pH}$ is an important pathogenetic mediator of the carcinogenic effects of arsenic salts [14], as has been reported in other parallel studies by different groups of researchers $[4,8-10,13,25,28]$. This is in line with previous reviews reporting a cause-effect relationship of a high microenvironmental $\mathrm{pH}$ and/or NHE stimulation with both $\mathrm{pH}$-directly and $\mathrm{pH}$-indirectly carcinogenesis, with the effects of a high $\mathrm{pH}$ reproducing most of the characteristics and metabolic behaviour of cancer cells [11].

Importantly, these complex dynamics of $\mathrm{pH}$-metabolism engage the cell in a vicious cycle from very early on: the oncogene-driven alkalinization increases glycolysis and proliferation which, by generating a need for a high energy consumption, creates a high proton production that activates various proton efflux transport systems resulting in a further alkalinisation of the cell. This even further reduces oxidative phosporylation (OXPHOS) and increases glycolysis. This "chain-reaction" of deep-seated and dynamically disregulated $\mathrm{H}^{+}$energetics creates a "perfect storm for cancer progression" [2]. Finally, to our knowledge the pathological alkaline $\mathrm{pH}_{\mathrm{i}}$ of tumor cells and tissues have never been described in any other type of cell or disease other than malignancy $[29,30]$. This adds further weight to the paradigm concerning the specificity and selectivity of these $\mathrm{H}^{+}$-mediated, deep-seated energetic abnormalities regarding the advantageous thermodynamics of the malignant process.

Indeed, this "basic" and specific abnormality of the relationship between the intracellular and the extracellular proton dynamics ("proton gradient reversal") represents 
a phenomenon that is increasingly considered to be one of the most differential hallmarks of cancer $[4,5]$. This severe abnormality in cell physiology has led to the formation of a unifying thermodynamic view of malignancy, a comprehensive new paradigm able to encompass an enormous and scattered bulk of information in the main areas of research that embraces many different and so far poorly interconnected cancer fields. These range from etiopathogenesis, cancer cell metabolism, multiple drug resistance (MDR), neovascularization and the metastatic process to selective apoptosis, cancer chemotherapy, cancer epidemiology and even the, so far poorly understood, phenomenon of the spontaneous regression of cancer [27,31,32]. Further, the increased diffusion of the proton ions along concentration gradients from tumors into adjacent normal tissues creates a pericellular and peritumoral acidic microenvironment involved in driving destruction of the surrounding normal limitrophic tissue, invasion and metastasis. Both the acidic $\mathrm{pH}_{\mathrm{e}}$ and the constitutively active NHE1 play a key role in driving protease-mediated digestion and remodelling of the ECM and the turning on of invasive phenotypes of the cell, scavenging normal tissue and increasing motility through the formation of invasive structures such as leading-edge pseudopodia and invadopodia [4,6,33-35] (Figure 1). Furthermore, focal cell to cell adhesions are particularly located at the cell front where NHE1 is concentrated. These sites feature a remarkably alkaline cytosolic and an acidic pericellular $\mathrm{pH}$ and thus a much steeper proton gradient across the plasma membrane compared to the rest of the cell [36]. Most recently it has also been advanced that that deregulation of NHE1 activity is a major factor leading to metastasis in human breast cancer [37]. Altogether, this clearly indicates that therapeutic targeting of the main proton transporters that are selectively overexpressed in cancer cells could be highly specific for malignancy, and is likely to open new pathways towards the development of more effective and less toxic chemotherapeutic measures for all solid malignant tumors and leukaemias [5,38-40].

\section{The pH of cancer cells and the Warburg Effect: a synthetic explanation}

Even from the time of Warburg's death in 1970 the idea that the shift to glycolytic metabolism relative to OXPHOS under aerobic conditions could be explained by an increase in the intracellular $\mathrm{pH}$, has been increasingly gaining weight with the passing of time $[8,28,41-44]$. Nagata et al., have recently reached a synthetic conclusion: that the Warburg effect may be simply, and perhaps fully explained by the elevation of $\mathrm{pH}_{\mathrm{i}}$ in cancer cells [44]. These groups have also shown that malignant alkalinisation drives the initial activation of aerobic glycolysis (first appearance of the Warburg Effect) [44,45]. In the presence

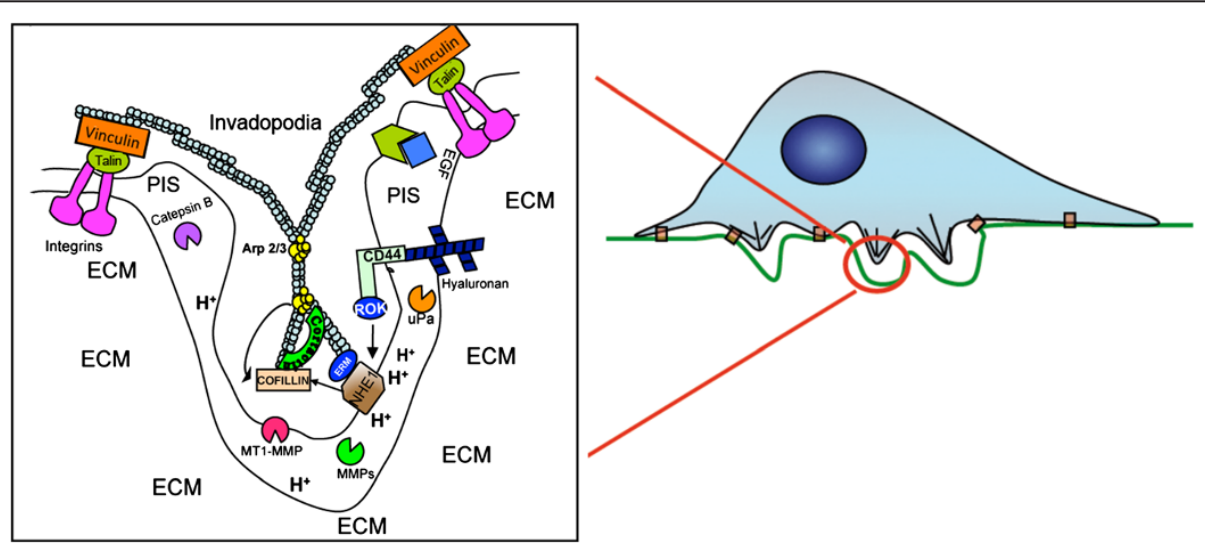

Figure 1 Model of localization and role of NHE1 in invadopodia. The insert is a magnification of the F-actin-enriched cellular protrusions into the ECM that are responsible for ECM degradation and are known as invadopodia. Invadopodia formation is activated by integrin binding to the ECM and their activity further increased through the CD44 (activated by its ligand Hyaluronan) and EGFR receptors located in the membrane. The integrin receptors are connected to the cytoskeleton (blue circles) through the proteins Talin and Vinculin. The proteases cathepsin $B$, D and $L$, Urokinase Plasminogen Activator and the matrix metalloproteinases MMP-2 and MMP-9 are released extracellularly while the MT1-MMP is localized within the membrane and participates together with Cathepsin B in the processing of inactive pro-MMP-2 into active MMP-2. Glycolytic enzymes are enriched in invadopodia, leading to the localized production of protons. These protons are secreted via an active NHE1 that is recruited to the invadopodia through integrin binding and further stimulated by CD44 and EGFR. NHE1 with its two functions (scaffolding protein and ion exchanger) leads to membrane protrusion and proteolysis. As a proton transporter, NHE1 promotes invasion through its control of the acidification of the peri-invadopodial space where NHE1 proton secreting activity and proteases act in concert to degrade the ECM during invasion. Further, the NHE1-dependent alkalinization of the invadopodia cytosol results in a phosphorylation of cortactin with the subsequent release of cofilin which promotes actin polymerization, growth of the invadopodia cytoskeleton and invadopodia protrusion. Secondly, NHE1 also promotes invadopodial formation via its interaction with the cytoskeleton through its binding to the actin anchoring protein, ezrin, which, reciprocally is responsible for the localization of NHE1 to the invadopodia in response to ECM and growth factor receptor activation. PIS: Perilnvadopodia Space; ECM: ExtraCellular Matrix. Please see text for discussion and references. 
of adequate oxygen levels, the intracellular $\mathrm{pH}$ plays a key role in determining the way cancer cells obtain energy: an alkaline $\mathrm{pH}_{\mathrm{i}}$ driving aerobic glycolysis and an acidic $\mathrm{pH}$ driving oxidative phosphorylation [28]. An explanation for this phenomenon derives from the fact that both the processes of OXPHOS and glycolysis are exquisitely but oppositely $\mathrm{pH}$ sensitive and a rapid shift of cell metabolic patterns follows either acidification or alkalinisation. On the one hand, it has been known for decades that an alkaline $\mathrm{pH}_{\mathrm{i}}$ even slightly above steady-state levels stimulates the activity of key glycolytic enzymes such as phosphofructokinase (PFK-1) and inhibits gluconeogenesis $[8,41,42,46,47]$. Indeed, in cancer cells a high $\mathrm{pH}_{\mathrm{i}}$ situation can increase the allosteric regulation of PFK1 more than 100-fold [2,8]. This also has important diagnostic consequences. We know that the selectivity of PET technology is based upon the degree of tumor glycolysis. Tumoral glycolysis is to a great extent dependent on $\mathrm{pH}_{\mathrm{i}}$, increasing with cellular alkalinity and decreasing with intracellular acidification. This feature opens a diagnostic potential for the development of new radiological methodologies based on the determination of the intracellular acid-base status. Thus, measurements of the $\mathrm{pH}_{\mathrm{i}}$ in malignant tumors, and even premalignant conditions, could become a better diagnostic tool than PET technology in determining the presence of a tumor, and could also detect higher than normal $\mathrm{pH}_{\mathrm{i}}$ areas $(>7.2 / 7.3)$ where malignancy is most likely to develop and eventually manifest itself [35,48-51]. Finally, hypoxia $\left(\right.$ low $\mathrm{pO}_{2}$ ) or alkalosis (high $\mathrm{pH}_{\mathrm{i}}$ or low intracellular $\mathrm{H}^{+}$-concentration) show similar effects on cell intermediary metabolism as well as a parallel transforming potential [11]. Indeed, the transforming effects of a high $\mathrm{pH}_{\mathrm{i}}$ are known as "para-hypoxia" and the carcinogenic effects of hypoxia as the "WarburgGoldblatt effect", after Goldblatt induced malignant transformation of cells kept in relatively low $\mathrm{O}_{2}$, non-killing conditions during Warburg's time (Table 2) [11,52]. Indeed, it can now be considered that the high $\mathrm{pH}_{\mathrm{i}}$ of tumor cells, the Warburg effect and the steady-state cancer cell proton reversal may very well represent one and the same phenomenon observed from different perspectives, at different historical times and through less outreaching and integral perspectives.

\section{Back to beginnings: a fatal historical error?}

To understand the full significance of the most recent observations and data we need to go back in time to the beginnings of cancer biochemistry, and so, to the postulated origin of cancer cells $[53,54]$. By doing so we realize that a fundamental confusion in the entire field of metabolic and biochemical cancer research was created from its very beginning. Nowadays, it is clear that Otto Warburg was wrong on the main point of his famous theory, namely, on the levels of cancer cell $\mathrm{pH}_{\mathrm{i}}$, and consequently
Table 2 Similarities of effects of a high pH - Low $\left[\mathrm{H}^{+}\right]$or (Alkalosis) and low $\mathrm{pO}_{2}$ (Hypoxia) on cellular biochemistry and metabolism

\begin{tabular}{ccc}
\hline & Hypoxia & Alkalosis \\
\hline Glycolysis & $\uparrow$ & $\uparrow$ \\
Phosphofructokinase & $\uparrow$ & $\uparrow$ \\
Pyruvate production & $\uparrow$ & $\uparrow$ \\
Lactate production & $\uparrow$ & $\uparrow$ \\
& (Anaerobic glycolysis) & (Aerobic \\
Alycolysis) \\
Mitochondrial oxidation & $\downarrow$ & $\downarrow$ \\
Transforming/oncogenic & $\downarrow$ & $\downarrow$ \\
effect & + & + \\
& (Goldblatt-Warburg & (The Warburg \\
& effect) & effect) \\
\hline
\end{tabular}

$\uparrow$ Stimulation; $\downarrow$ Inhibition.

For further details, see text and reference [11].

Note: Reprinted from Critical Reviews Oncogenesis, vol. 6. Harguindey S, Pedraz JL, Garcia Canero R, Perez de Diego J, Cragoe EJ, Jr. Hydrogen ion dependent oncogenesis and parallel new avenues to cancer prevention and treatment using a $\mathrm{H}(+)$-mediated unifying approach: $\mathrm{pH}$-related and $\mathrm{pH}$-unrelated mechanisms, p. 6, @1995, with the permission from Begell House, Inc.

on its relationship to glycolysis. Indeed, Warburg believed that the $\mathrm{pH}$ of cancer cells was acid because of their high production rates of lactic acid [55-57]. Probably, the main reason for overlooking the true $\mathrm{pH} /$ glycolysis relationship, or at least for being given a secondary role at that time was that, during the 60's and 70's, the necessary technology to measure $\mathrm{pH}_{\mathrm{i}}$ was not available [58]. The situation started to turn around just after Warburg's death in 1970, when different reports began to emphasize that the $\mathrm{pH}_{\mathrm{i}}$ of cancer cells was the opposite from what was generally thought during Warburg's life $[18,41,43,58]$. Thus, Warburg could not have been aware that cellular alkalosis not only activates glycolysis but at the same time hinders oxidative phosphorylation and the entrance of pyruvate in the Krebs cycle $[42,59]$. This allows a further insight into the reasons behind decades of confusion and disagreements on his theory of "the abnormal respiratory mechanisms of cancer cells", that he defended all his life [8,28,42,53,59-61]. It is also important to remember that at Warburg's time there were not techniques permitting the discrimination between the $\mathrm{pH}$ of the cytosol and of the internal organelles. Today we are able to show that within tumor cells the cytosol is alkaline while the cytoplasmic vesicles are very acidic [62,63]. This is possible thanks to proton pumps, on one side eliminating protons outside the tumor cell when expressed on the plasma membrane, while pumping them from the cytosol to the internal lumen of the acidic vacuoles in order to avoid internal acidification (reviewed in [64]).

Importantly, any consideration concerning the intimate relationship of high $\mathrm{pH}_{\mathrm{i}}$ and glycolysis was fully missed during the famous arguments between Warburg and 
Weinhouse published in Science in 1956 [61,62]. Indeed, all those heated discussions could only beg the real issue and could have been obviated if the true effect of $\mathrm{pH}$ on anaerobic and aerobic glycolysis and oxidative phosphorylation ("parahypoxia") [11] could have been taken into account. Probably, this is also the main reason behind the fact that the search for the real cause underlying the Warburg effect has created many disagreements over the last decades $[3,56,61,63-71]$. All in all, it can now be said that Warburg was right up to a certain point but that his critics were also partially right. However, all of them missed the main point. Aerobic glycolysis or damaged respiration was not the primary cause of cancer, as Warburg defended until his death. Indeed, the primary cause of cancer appears to be, precisely, the main cause of the aerobic glycolysis of tumors: a profound disruption of the homeostatic acid-balance of the cell mainly represented by an abnormally high $\mathrm{pH}_{\mathrm{i}}$ mediated by an extremely varied number of etiological factors of different natures. In summary, cellular alkalosis represents a common final pathway in cell transformation induced by a myriad of different stimuli, from oncogenes to virus to mitogens to growth factors and hormones to gene products $[1,4,8-10,27]$. Finally, some recent and otherwise complete reviews dealing with Warburg's contributions to modern concepts in cancer metabolism, tumor glycolysis, the initiation of cancer and oxidative phosphorylation have not considered the tight cause-effect interrelationships between $\mathrm{pH}$ and glycolysis, the Warburg effect and cancer proton reversal $[65,68,69,72,73]$.

\section{Anticancer potential of NHE inhibitors. Background to recent developments}

The development and maintenance of this reversed $\mathrm{pH}$ gradient is directly due to the ability of the tumor cells to secrete protons $\left(\mathrm{H}^{+}\right)[1,4,27,74]$. This proton secretion depends on the buffering capacity of the cell and is driven by a series of membrane-bound proton transporters (MBPT), mainly the $\mathrm{Na}^{+} / \mathrm{H}^{+}$exchangers but also carbonic anhydrases (CAs, mainly CA IX and XII), vacuolar $\mathrm{H}^{+}$-ATPases, the $\mathrm{H}^{+} / \mathrm{Cl}^{-}$symporter, the monocarboxylate transporter (MCT, mainly MCT1), also known as the lactate-proton symporter, the $\mathrm{Na}^{+}$-dependent $\mathrm{Cl}^{-}$/ $\mathrm{HCO}_{3}{ }^{-}$exchangers and ATP synthase [1,5,40,74-77], each of them having its specific inhibitors (Figure 2). The human NHE (SLC9) family is comprised of nine A isoforms (SLC9A1-9) with one established (NHE6) and one possible (NHE1) splice variant and five pseudogenes plus two B isoforms (SLC9B1/2) and two C isoforms (SLC9C1/2) [78]. (For a more detailed information about the SLC gene tables, please visit: http://www.bioparadigms.org).

Among them, the most important, functionally active, cancer-selective and better studied is the $\mathrm{Na}^{+} / \mathrm{H}^{+}$exchanger isoform one, NHE1 [79-81]. The NHE1 is specifically involved in cellular acid-base balance and is the predominant isoform expressed in tumors, where it has been shown that it contributes to cellular $\mathrm{pH}$ homeostasis, cell transformation, proliferation, motility, migration, tumor growth, invasion, activation of the metastatic process, resistance to chemotherapy and probably also to the spontaneous regression of cancer [4,31,37,82-84]. Conversely, decreasing NHE1 expression or inhibiting NHE1 activity leads to tumour cell growth arrest, inhibition of glycolysis, acidification of the intracellular space and selective apoptosis $[29,38,45,82]$. An elevated NHE1 activity is considered to be the major factor in promoting tumor extracellular/interstitial acidity from even the earliest pre-cancer stage of oncogene-driven neoplastic transformation $[25,26]$. However, large studies of patient cohort samples demonstrating that NHE1 is overexpressed in human tumors are lacking. Also, some cancer cells can be NHE1 negative and maintain cytosolic alkalinisation through expression of other MBPT $[40,85]$. Consequently, NHE1 inhibitors appear predestined to be taken advantage of as a therapeutic target in probably most types of human cancer [81,86-89]. For a detailed review of the structure and biophysical characteristics of NHE1, the regulation of the NHE1 activity and its role in tumor cells $\mathrm{pH}$ homeostasis, please refer to recent publications $[2-4,79,80,90]$.

Beyond studying in depth the evolution and progress of biochemical and metabolic cancer research, a major purpose of this review is to consider the fact that the new and selective NHE1 inhibitors show promise to become potent anticancer agents in preclinical trials and, eventually, in cancer patients. Amiloride was the first NHE inhibitor developed and it was shown to decrease vasoendothelial growth factor (VEGF) production and the activity of urokinase-type plasminogen activator $(\mu \mathrm{PA})$, metalloproteinases (MMP) and other proteases, all of which aid in the activation of the metastatic process [89,91-94]. Amiloride alone was shown to achieve a complete in vivo anti-metastatic effect in transplanted tumors in rats [95]. Indeed, there are occasional reports of long-term treatment with amiloride in humans achieving remissions of cancer after chemotherapy had failed to control disease progression [96]. Recent publications on the use of amiloride in cancer therapy discussed the different studies where its use had clear anti-neoplastic effects with few side-effects [97]. Long before this, the utilization of amiloride and its derivatives were proposed as anticancer agents in bedside oncology [86]. This potassium-sparing diuretic, apart from having a direct antitumoral, antimetastatic and antiangiogenic effect $[95,97,98]$, at least in part by inhibiting uPA and VEGF, has been shown to be well tolerated and safe when used in the chronic situation in pharmacological dosages in humans, the main side-effect being occasionally increased plasma $\mathrm{K}^{+}$levels $[96,99,100]$. Since more selective and powerful NHE inhibitors, like cariporide, are not 


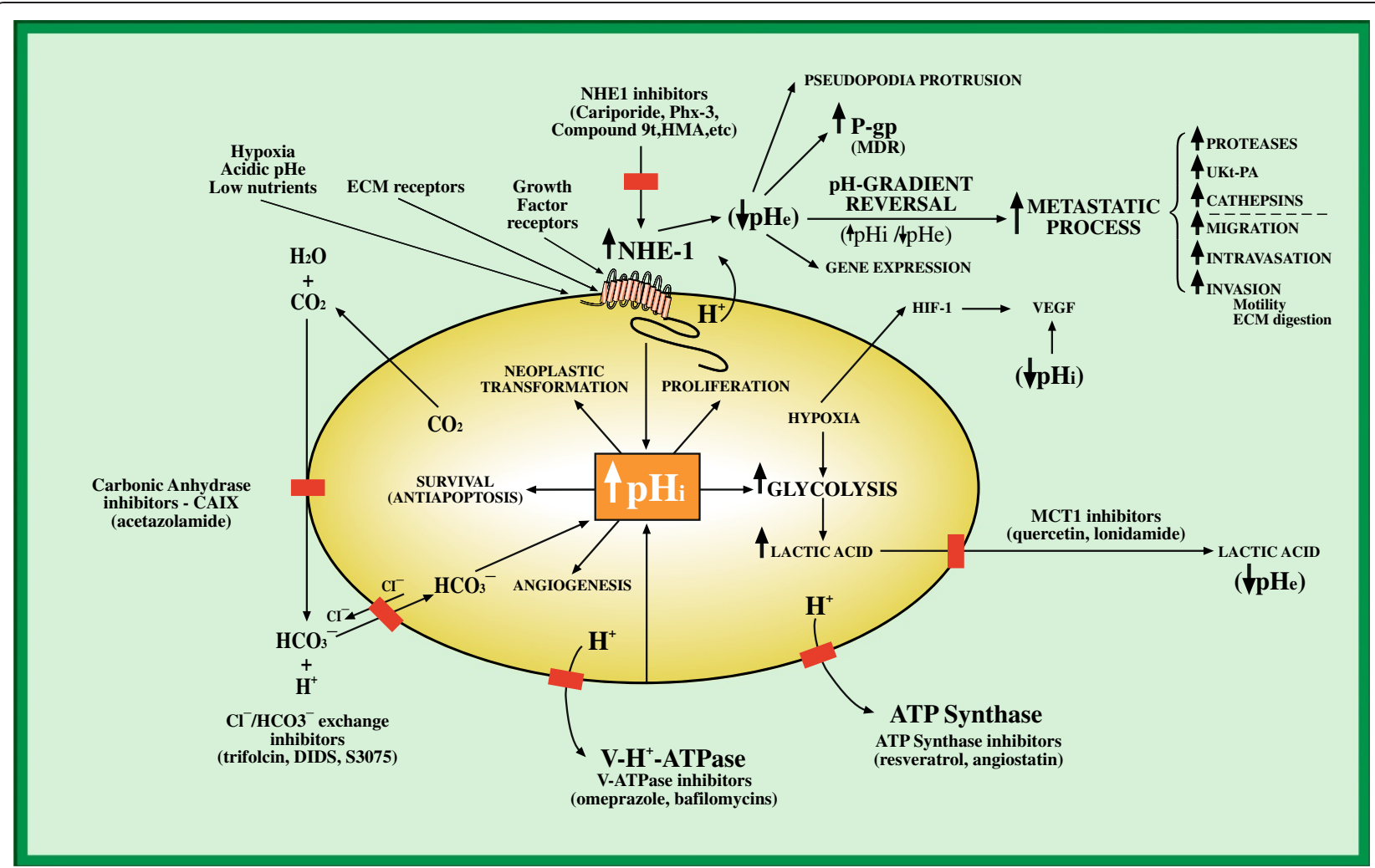

Figure 2 Dysregulated pH-control systems in cancer cells. Targets for proton transport inhibitors (PTIs) as anticancer agents. Nos. 1, 2, 3, 4, 5 and 6: Mechanisms that induce intracellular alkalinisation as the key factor in cell transformation and progression with its secondary abnormalities. Secondary $\mathrm{pH}_{\mathrm{i}}$-dependent extracellular acidification, $\mathrm{pH}$-gradient reversal and hypoxia as triggers for the metastatic process. Five targets for inhibition of proton extrusion of cancer cells as targets for metabolically-directed anticancer treatment and examples of drugs of the different proton transport inhibitors at the sites of their activity. For further details see text and ref. [5] Abbreviations: $\mathrm{NHE1}$ : $\mathrm{Na}^{+} / \mathrm{H}^{+}$exchanger: HMA; 5-(N,N-hexamethylene)amiloride; Phx-3: 2-aminophenoxazine-3-one; Compound 9 t: 5-aryl-4-(4-(5-methyl-1H-imidazol-4-yl) piperididn-1-yl)pyrimidine analog; HIF-1: hypoxiainducible factor; MCT1: monocarboxylate transporter or $\mathrm{H}^{+}$-lactate co-transporter; CAIX: carbonic anhydrase IX; V-H ${ }^{+}$-ATPase: vacuolar $\mathrm{H}^{+}$-ATPase; VEGF: vasoendothelial growth factor; UKT-PA: urokinase-type plasminogen activator; P-gp: P-glycoprotein; MDR: multiple drug resistance; $\mathrm{pH}_{\mathrm{i}}$ : intracellular pH; $\mathrm{pH}_{\mathrm{e}}$ : extracellular/interstitial tumoral $\mathrm{pH}$.

available for human use, amiloride should still be part of new protocols dealing with the concerted use of a cocktail of proton transport inhibitors (PTIs) in different human solid tumors $[5,96,101]$.

For many years investigators have waited for more specific and potent NHE inhibitors to be developed and be made available to the clinician [102]. In this vein, powerful amiloride analogues, like ethylisopropylamiloride (EIPA), have been studied in different settings regarding its anticancer potential [103-105]. Hexamethylamiloride (HMA) and dimethylamiloride (DMA), were also introduced in basic experimental research and provided additional evidence of the validity of this approach. Striking results in different kinds of leukemic cells were reported with the potent NHE1 inhibitor HMA, which specifically decreases the $\mathrm{pH}_{\mathrm{i}}$ well below the survival threshold leading to selective apoptosis in a variety of human leukemic cells [38]. This has led to the consideration that inducing a low $\mathrm{pH}_{\mathrm{i}}$-mediated apoptosis as a cancer-specific therapeutic modality for all cancer cells and tissues could be a new and original approach to clinical therapeutics $[27,39,44,76,106]$. Regarding NHE-related malignant angiogenesis, the activity of a significant number of proangiogenic factors and oncogenes has been shown to positively affect NHE1 expression while, on the contrary, a wide array of anti-angiogenic drugs inhibit NHE1 $[107,108]$. In summary, a great deal of evidence has been accumulating showing that the NHE is an important, and possibly selective, anticancer target $[11,81,86,87,89,100]$. The pharmacology and therapeutic possibilities of the rest of the different proton transporters besides NHE1 have been thoroughly reviewed recently and will not be further dealt with here $[4,75,81,83]$.

\section{Cariporide's anticancer potential}

It has been demonstrated that treating various kinds of cancer cells with selective and potent inhibitors of NHE1, including cariporide, suppresses their invasive capability [37,109-111].

Di Sario et al., have also shown that cariporide, through its selective inhibition of NHE1 and subsequent decrease 
of intracellular $\mathrm{pH}$ reduces proliferation and induces apoptosis in cholangiocarcinoma cells [112], leading these authors to suggest the potential therapeutic value of cariporide against this human tumor. A recent review has also focused on how to therapeutically target the NHE1mediated metabolic transformations of cancer cells with cariporide [64]. However, translation to the oncology clinic has yet to be realized because, unfortunately, the utilization of this drug in cancer treatment has not been explored $[4,84]$ and there is scarce data on NHE1 upregulation in tumour cells [40]. This is most important since the concerted utilization of less potent and specific inhibitors of NHE1 and other proton transport inhibitors (PTIs) was recently advanced as a new, selective and integrated anticancer strategy [5,101] (Figure 2).

The only non-amiloride based compounds with NHE1 inhibitory activity that have undergone clinical trials are cariporide and eniporide, and, unfortunately, those trials were not in the field of cancer but in a cardiological setting and for ischaemic-reperfusion injury. An early study on the effect of cariporide in 100 patients waiting to receive perfusion therapy via primary coronary angioplasty within 6 hours of the onset of symptoms suggested that reperfusion injury could be a target for NHE inhibitors and these results led to further clinical trials to confirm the therapeutic potential of NHE inhibitors [113]. Two were with cariporide: The "Guard During Ischemia Against Necrosis" (Guardian) $[114,115]$ and "The $\mathrm{Na}^{+} / \mathrm{H}^{+}$Exchanger Inhibition to Prevent Coronary Events in Acute Cardiac Conditions" (EXPEDITION) [116]. The "Guardian" trial included a total of 11590 patients with unstable angina or a myocardial infarction who received placebo or different doses (30, 80 and $120 \mathrm{mg}$ ) of cariporide. There were an early clinical benefit and elevated six month survival rate in only a group of patients requiring urgent coronary bypass graft surgery and at a cariporide level of $120 \mathrm{mg}$. There was also a trial utilizing eniporide: "The Evaluation of the Safety and Cardioprotective Effects of Eniporide in Myocardial Infarction" (ESCAMI) [117].

Despite the cardioprotective value of cariporide in reducing myocardial infarcts in both the EXPEDITION and in the earlier GUARDIAN trials, use of the drug was associated in the EXPEDITION study with a significant increase in the rate of mortality (from $1.5 \%$ to $2.2 \%$ at day 5) due to an increase in cerebrovascular events $[116,118]$. The appearance of these adverse effects in the last trial can probably be ascribed to the higher cumulating dose of cariporide administered in the EXPEDITION trial with respect to the GUARDIAN trial [119].

Clearly, a clinically reasonable initial approach in an oncology setting would be to minimize the systemic dose of the drug in order to dissociate the adverse and probably off-targets effects from the beneficial effects. Interestingly, rats having a lifelong treatment with cariporide had a greatly extended lifespan and this was interpreted as being due to a reduced occurrence of cancer [120]. Finally, cariporide has been shown to be useful in overcoming multiple drug resistance (MDR) and the activity of the metastatic process [121]. Besides, it is orally bioavailable and by this route of administration has been used but, unfortunately, never to date as an anticancer drug [114-119,122-125]. Interestingly, hypoxia is part of the tumor metabolic microenvironment and has been shown to activate NHE1 and consequent invasion [109,126,127]. Cariporide reduces hypoxia-mediated tumor invasion of human tongue squamous cell carcinoma by inhibiting NHE1 [128]. In this study, the authors demonstrated that inhibition of NHE1 by cariporide (HOE642) suppressed the invasion and migration of Tca8113 cells under hypoxic conditions. In another study pharmacological inhibition of p38 MAPK (mitogen-activated protein kinase) also significantly suppressed C/EBP $\alpha$ expression under hypoxia conditions after NHE1 inhibition [110]. These results indicate the enhancement of hypoxia-induced K562 differentiation by NHE1 inhibition, which may be due to up-regulation of $\mathrm{C} / \mathrm{EBP} \alpha$ via $\mathrm{p} 38$ MAPK signalling pathway, which suggests a possible therapeutic target of NHE1 under hypoxia microenvironment in the treatment of leukaemic diseases. Finally, this also suggests that NHE1 inhibitors could be combined in clinical trials with antiangiogenics $[129,130]$ because tumor hypoxia and/or acidosis also stimulates VEGF [131,132].

Indeed, in addition to VEGF release and, subsequently, neoangiogenesis, being stimulated by hypoxia, upregulation of VEGF has also been linked as being secondary to acidic $\mathrm{pH}_{\mathrm{e}}[131,133]$. Also, NHE1-dependent lowering in $\mathrm{pH}_{\mathrm{i}}$ also reduces the release of VEGF from the tumor cell so hindering motility and invasion $[38,134]$. Systemic amiloride treatment also reduced experimentally-induced neovascularization in an animal model; probably through inhibition of NHE1 [135]. For more detailed information please refer to the following review [107]. Importantly, the potency of cariporide and some other NHE1 inhibitors is related to the ionization state of the guanidine residues. In this respect, the acidic extracellular $\mathrm{pH}$ of tumors (which can be as low as 6.2) will render zoniporide $\left(\mathrm{pK}_{\mathrm{a}}=7.2\right)$, TY-12533 $\left(\mathrm{pK}_{\mathrm{a}}=6.93\right)$ and, especially, cariporide $\left(\mathrm{pK}_{\mathrm{a}}=\right.$ 6.28) positively charged. Therefore, the acidic tumor microenvironment could turn out to be an advantage in terms of dose-dependent side-effects as these compounds would be more efficient at inhibiting NHE1. Indeed, cariporide would be even more active at a very low $\mathrm{pH}_{\mathrm{e}}$ (ie. $\mathrm{IC}_{50}=22 \mathrm{nM}$ vs $120 \mathrm{nM}$ at $\mathrm{pH}_{\mathrm{e}} 6.2$ and 6.7, respectively) [136-138]. Finally, the development of new non-guanidine derived NHE1 inhibitors could alleviate some of the detrimental side-effects found in the Expedition trial (see section below on the new and potent non amiloride-derived and non guanidine-derived compounds). 
The role of $\mathrm{pH}$ in multiple drug resistance (MDR) Cariporide and other proton transport inhibitors in the overcoming of MDR

pH, MDR and cancer A direct cause-effect relationship among MDR and the elevation of $\mathrm{pH}_{\mathrm{i}}$ in cancer has been recognized by different groups of researchers [83,139-141]. On the contrary, the failure of tumor cells to die following chemotherapeutic treatment appears to be highly dependent on their resistance to undergo intracellular acidification, a situation that is apparently necessary as a prior and early condition that allows cancer cells to engage in a tumor-specific apoptotic process [38,44,45,106,112,142] (Figure 3). Cancer cells are known to establish a dynamic and well organized self-defensive anti-apoptotic strategy ("the neostrategy of cancer cells and tissues") [27] which is mediated through different anti-acidifying mechanisms such as hyperactivity of the group of membrane-bound proton extrusion transporters, inactivation of $\mathrm{Bcl}-2, \mathrm{Bcl}_{-\mathrm{xl}}$ and/or a pH-dependent de-stabilization of p53 [12,13,139]. These concerted dynamic changes work as an antichemotherapeutic shield involved in multiple drug resistance (MDR) and in the development of newly resistant subpopulations of tumor cells $[1,143]$. The final therapeutic aim is to target this selective acid-base disruption of cancer cell metabolism based on the $\mathrm{H}^{+}$-dependent thermodynamic advantages that malignant cells possess for their evolutionary survival as compared to their normal counterparts in order to exploit such differences in selective cancer therapeutics [144-146]. This can be achieved with the concerted utilization of proton transport inhibitors (PTIs) as primary treatment and also as an adjuvant measure in overcoming MDR, increasing therapeutic specificity and effectiveness regardless of tumor type and origin $[4,82,83]$. Besides, drugs of the amiloride series and/or other proton transport inhibitors (PTIs), apart from reversing cancer proton reversal also induce VEGF inhibition, so behaving as antiangiogenic drugs $[20,92,107,147]$. Furthermore, various anticancer drugs including adriamycin, cisplatinum, paclitaxel and camptothecin do not induce apoptosis under non-acidified intracellular conditions [148-151]. Also, resistance to several anticancer drugs such as camptothecin, vinblastine, adriamycin, and etoposide, has been correlated with overexpression of different proton transporters and/or intracellular alkalinization $[4,20,83,139,140]$. Besides, it should be taken into account that cytosolic acidification is a very early event in the onset of malignant cell apoptosis [106,152]. These MDR modifiers include verapamil, amiodarone, Bafilomycin $A_{1}$, cyclosporine $A$, tamoxifen, 4,4' -diisothio-cyanatostilbene-2,2'-disulfonic acid (DIDS), nigericin, cariporide and edelfosine [11].

This $\mathrm{H}^{+}$-based "basic" approach to MDR-related cancer therapeutics may lead to more selectivity and less toxicity

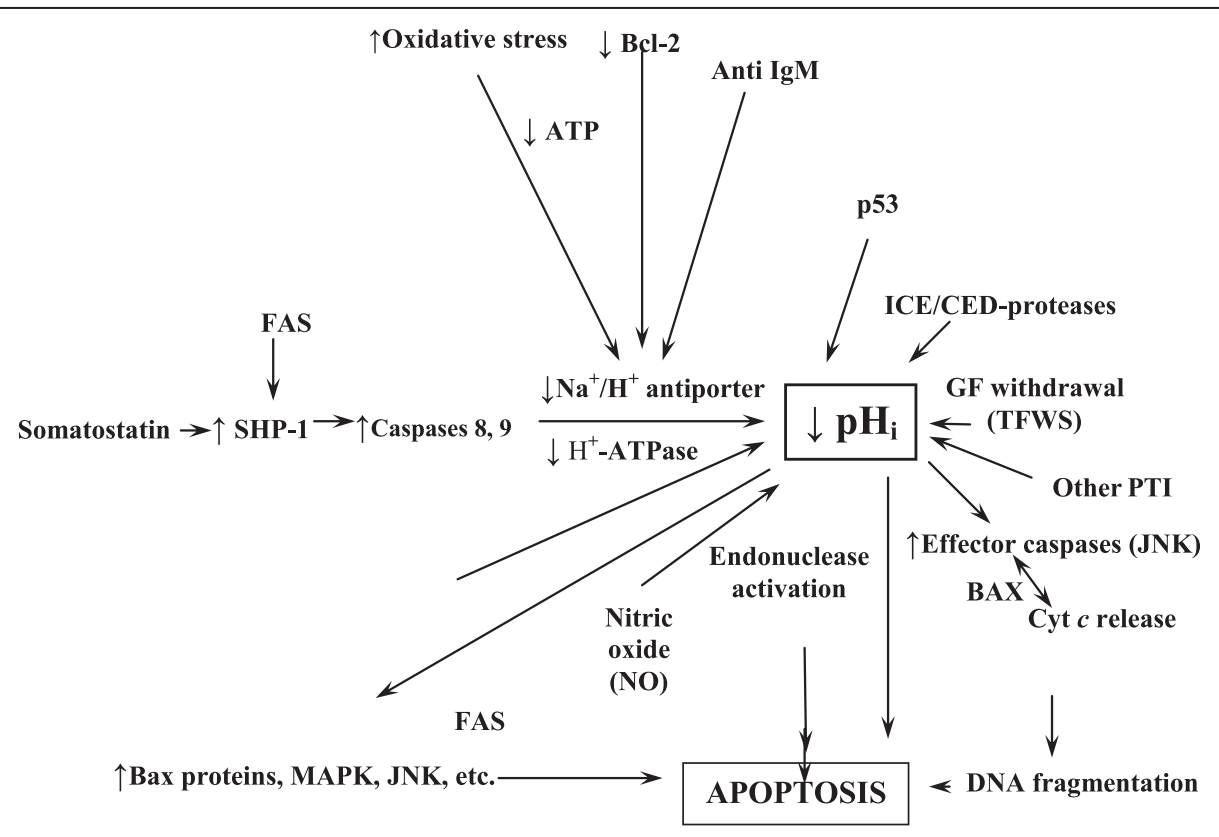

Figure 3 Intracellular signaling factors and mechanisms targeting $\mathrm{pH}_{\mathrm{i}}$ and the $\mathrm{Na}^{+} / \mathrm{H}^{+}$exchanger in the apoptosis of cancer cells. This integrated and homeostatic pH-related perspective can help to foretell pro-apoptotic and anti-apoptotic factors in order to find synergistic therapies and potential antagonisms (MDR) in anticancer treatment. Abbreviations: $\uparrow$ : Stimulation; $\downarrow$ : inhibition; SST: somatostatin; SHP1: protein tyrosine phosphatase; MDR: multiple drug resistance; GFs: growth factors; Cyt C: cytochrome C; NO: nitric oxide. TFWS: trophic factor withdrawal syndrome; aCD95 (Fas/Apo-1) death receptor; JNK: Jun-terminal kinase; MAPK: mitogen-activated protein kinase; PTI: proton transport inhibitors; ICE: interleukin-1 $\beta$-converting enzyme. (For further details, see text and refs. [5,29,30]. (Modified from refs. [5,29] by permission from Dove Medical Press, Ltd., and Anticancer Research). 
of other chemotherapeutic agents if used together with the most potent and selective PTIs known to date, like cariporide, Phx-3 or Compound 9 t $[44,81,124]$. Cariporide also increases the effect of gemcitabine in human cholangiocarcinoma cells by inhibiting MDR [12]. Further along this line, the inhibition of the NHE1 has been shown to play a fundamental role in paclitaxel-induced apoptosis of breast cancer cells and this is synergistically potentiated by dimethyl amiloride (DMA) [121]. This is reasonable since this counteracts the overexpression/ activation of the NHE1 which appears to contribute to the onset and/ or maintenance of MDR [5,81-83]. Thus, cariporide, because of its powerful effect in inhibiting NHE1, can also become a fundamental drug in overcoming MDR in human cancer therapy.

MDR, proton transport inhibitors (PTI), pH and Pglycoprotein (P-gp) In the same vein, De Milito et al. have shown that following PPI treatment of melanoma cells with esomeprazole overcomes MDR and undergo a significant decrease of proton gradient reversal, inducing tumor cell death via rapid intracellular acidification [153-155]. Also, the simultaneous inhibition of the NHE1 and $\mathrm{H}^{+}$-ATPase induces apoptosis through their concurrent effects on lowering $\mathrm{pH}_{\mathrm{i}}[147,156,157]$. Finally, the relationships of NHE1 inhibition to tumor hypoxia, growth factors and antiangiogenic therapy have been extensively reviewed $[10,74,158]$ and will not be further dealt with in this contribution. For detailed information on NHE/AntiNHE drug-relationships, please refer to the following original publication [107].

Why is pH reversal so important in MDR? The drug handling and extrusion mechanisms mediated by P-gp glycoprotein can no longer fully account for MDR in cancer treatment $[82,106,159,160]$. Currently, a more integrated mechanism to explain resistance to anticancer drugs can be based upon the modification of tumor microenvironment through changes in the extracellular and intracellular $\mathrm{pH}[159,161,162]$. In this regard, MDR cells exhibit a significantly high $\mathrm{pH}_{\mathrm{i}}$ that accounts, at least in part, for the Pgp-mediated resistance [163] (Figure 4). The fact that cells with an active MDR transporter show such a degree of cytoplasmatic alkalinization has led some authors to conclude that P-gp can be mainly considered as a proton extrusion pump [159,161,162]. Further, P-gp activity is stimulated by the interstitial acidification of cancer tissues. Indeed, the therapeutic failure to induce cytoplasmic acidification has been proposed as the main underlying factor for MDR because it means resistance to the induction of low $\mathrm{pH}_{\mathrm{i}}$-mediated therapeutic apoptosis in either normal, slightly alkaline and/or highly alkaline cancer cells $[12,27,152,164]$. This cancer antiapototic situation can be secondary to the overexpression/hyperactivity of proton transporters [76,156], the MDR-promoting effects

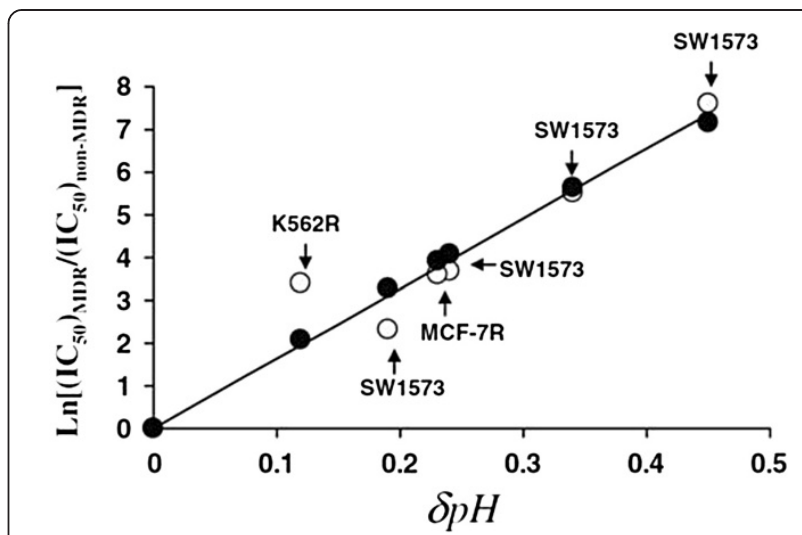

Figure 4 Impact of the changes in intracellular $\mathrm{pH}$ on doxorubicin resistance in different cancer cells. Multidrug resistance in cancer has been associated with the alkalization of the cytosol due to overexpression of proton pumps at the level of the cell membrane and/or expression of drug transporters. In this context it is believed that weak base drugs are protonated and as a result cannot cross the membrane bilayer, a feature that adds to the efficiency of drug transporters. Albeit this model (drug protonation and transporter) has been used over decades, the high pH of the cytosol can drive drug resistance through a different mechanism. The hypothesis made by us was that the change in cytosolic pH makes the membrane less permeable to drugs due to hydrogen-lipid interactions. To test this, a model of hydrogen-lipid interaction was formulated and compared with experimental data. In the figure the $\mathrm{X}$-axis represents the positive increment in the cytosolic $\mathrm{pH}$ when cells switch their state from being sensitive to resistant to drugs. The Y-axis represents the ratio of the logarithm values of the concentration of drugs to kill 50\% drug resistant vs. sensitive cells. The blank dots represent the experimental data. The black dots show the result expected from the theoretical modelling. The straight line represents the linear trend (best fit) from experimental data. Finally, the best fit passes across all the dots modelled by the theory. For further details see ref. [169].

of the Bcl-2 family of proteins [12], a dysfunctional p53 or the elevating cell $\mathrm{pH}$ effect of different growth factors $[17,19,22,23,165,166]$ (see above). Incidentally, an opposite $\mathrm{pH}_{\mathrm{i}}$ situation that occurs in malignancy, namely, a spontaneously occurring low $\mathrm{pH}_{\mathrm{i}}$-mediated pathological apoptosis appears to be important in the pathogenesis of certain neurodegenerative diseases, like Alzheimer's disease $[29,30,167,168]$. As we have previously considered, this suggests that the pathogenesis of cancer and certain neurodegenerative diseases can be at opposite ends of a pH-related metabolic spectrum [29]. Thus, from the point of view of apoptosis and antiapoptosis both situations are "opposite pathological processes".

MDR and the cell membrane It is well known that the principal mechanism that regulates the entry of a drug into a cell is the existence of $\mathrm{pH}$ gradients between the extracellular environment and the intracellular compartments [170-175]. The reason why the $\mathrm{pH}$ gradient across the membrane is so important is related to its ability to 
ionize drug chemicals. While depending on the drugs, be it weak acid or weak base, it is generally agreed that ionized drugs - i.e. bearing a net positive charge due to local $\mathrm{pH}$ conditions, will be less prone to cross the bilayer membrane than non-ionized drugs because of their resulting ability to interact with other biological compounds. Normal tissues have a neutral extracellular/ interstitial $\mathrm{pH}\left(\mathrm{pH}_{\mathrm{e}}\right)$ whereas the intracellular $\mathrm{pH}\left(\mathrm{pH}_{\mathrm{i}}\right)$ is slightly acidic. This should allow weakly basic drugs to enter passively into these cells. With weakly acid drugs it seems that the alkalinization of the cytosol of cancer cells can also impact on the lipid membrane by increasing the compaction of lipids making the membrane less permeable to chemicals independently of their ionization (see Figure 4) $[82,161,173,176,177]$. Since the increased interstitial acidity represents an advantage for the tumor to develop chemoresistance, using PTIs and/or PPIs will tend to normalize or even reverse the highly abnormal $\mathrm{pH}$ gradients in malignancy, leading to chemoresistance reversal.

These modifications of cancer $\mathrm{H}^{+}$dynamics are associated with regression or delay of tumor growth and also with enhanced response to chemotherapy [154,177-179]. It is suggested that the environmental conditions in tumors may allow the development of new and relatively specific therapies targeting the mechanisms regulating $\mathrm{pH}_{\mathrm{i}}$ under external acid conditions. Doxorubicin, cyclophosphamide, 5 -fluorouracil, vincristine, vinblastine, mitoxantrone, daunorubicin and chlorambucil are all clinically useful drugs, which are ionisable and hence their distribution will be affected by the microenvironmental $\mathrm{pH}_{\mathrm{e}}$ $[170,173-175,179]$. In any case, protonation is not necessarily detrimental to drug-target interaction if the target displayed is extracellular (e.g. extracellular part of NHE1). In addition, the detrimental aspect of $\mathrm{pH}$ on drug-target interaction concerns weak bases only (e.g. doxorubicin). Cariporide is a weak acid ( $\mathrm{pKa} \sim 4.5$ ) and therefore protonation is beneficial as far as drug-target interaction is involved [180], and doi https://www.ebi.ac.uk/chembldb/ index.php/compound/inspect/CHEMBL436559.

\section{On the relationship of $\mathrm{pH}_{\mathrm{i}}, \mathrm{pH}_{\mathrm{e}}$ and the NHE1 with tumor immunity}

Marches et al. elegantly showed the intimate link between cancer biochemistry, molecular biology and immunity by demonstrating that the anti-IgM-mediated induction of cell death in human B lymphoma cells is dependent on NHE1 inhibition and subsequent intracellular acidification, up to a point unifying those fields under one wider embracing unit [181]. In the same vein, it is accepted that the acid component of the tumor microenvironment directly impairs the function of the anti-tumoral immune system, thus contributing to the known in vivo immunosuppression by hindering a "host versus graft (the grafted malignant tumor)-like reaction". Exposure to increasingly acidic $\mathrm{pH}_{\mathrm{e}}$ has also been shown to reduce tumor cellinduced cytolytic activity of lymphokine-activated killer (LAK) cells $[182,183]$, to play a role in down-regulating cytolytic activity of tumor-infiltrating lymphocytes with natural-killer (NK) phenotype [184] and to inhibit the non-major histocompatibility complex (MHC)-restricted cytotoxicity of immunocompetent effector cells [185-188]. Most recently, it has been proposed that tumour-secreted lactic acid represents a major mechanism by which cancers can suppress the anti-cancer immune response [189]. This represents a further attempt to integrate different, so far separated fields, into larger and more all-comprehensive concepts [29], while at the same time introduces some fundamental MDR-related aspects of cancer immunity. It has also been recently shown that the NHE1, but not other isoforms, is an important mechanism in extruding $\mathrm{H}^{+}$and regulating $\mathrm{pH}_{\mathrm{i}}$ in immune cells themselves, such as monocytes and neutrophils, that need NHE1 to be activated to maintain an optimal $\mathrm{pH}_{\mathrm{i}}$ for an effective immune defensive role [190].

From a therapeutic point of view, it has been shown that it is possible to alkalinize in vivo the interstitial component of malignant tumors with sodium bicarbonate or other different buffers [191] and that either acute or chronic treatment of tumor-bearing mice with sodium bicarbonate or proton pump inhibitors results in an increased antitumoral activity of different anti-tumor drugs [1]. At the present time, preliminary preclinical and clinical trials are being conducted in order to overcome the anti-immune effects of the tumoral acid extracellular component when used together with immune-stimulating measures [191,192]. A recent clinical study performed in companion animals with spontaneous tumors has shown a clear chemosensitization through a combination of high dosage proton pump inhibitors (PPIs) with different cytotoxic drugs and in tumors of different histology. This data provides a clinical proof of concept that inhibition of extracellular tumor microenvironment acidification through PPIs, PTIs and/or certain buffers may be considered a pivotal new approach in integral anticancer strategies $[5,147,191-194]$. This is a new and underdeveloped area that needs further research in the future.

New and potent non amiloride-derived and non guanidinederived compounds (SL-591227, Phx-3, compound $9 \mathrm{t}$ ) as promising anticancer drugs

While amiloride and some of its first synthesized derivatives were non-selective and weak NHE inhibitors [195,196], an additional series of NHE1 inhibitors whose structure is independent of amiloride have been later developed. SL591227 was the first potent and NHE1 selective nonguanidine inhibitor $[105,113,197]$. The group of Tomoda developed two phenoxazine derivatives, Phx-1 and Phx-3 (for structures please see ref. [4]). Phx-3 is highly selective 
for NHE1 inhibition and was shown to selectively stimulate apoptosis in a variety of cancer cell lines while normal lymphocytes were not affected $[44,45]$. Also, PHx-3 also effectively reversed a subcutaneously injected adult Tcell leukaemia tumor growth in animal studies without noticeable toxicity (A. Tomoda, personal communication). Otherwise, researchers at Bristol-Meyers synthesized a 5aryl-4-(4-(5-methyl-1H-imidazol-4-yl)piperididn-1-yl)pyrimidine analog (compound $9 \mathrm{t}$ ) that was reported to have an excellent NHE1 inhibitory activity $\left(\mathrm{IC}_{50}=0.0065 \mu \mathrm{M}\right)$, to be 500 -fold more potent against NHE1 than cariporide and to have much greater selectivity for NHE1 over NHE2 (1400-fold). Besides, compound 9 has a reported $52 \%$ oral bioavailability, a plasma half-life of 1.5 hours in rats, low side-effects in mice and may possess a significantly improved safety profile over other NHE1 inhibitors [198]. Unfortunately, there have been no further publications utilizing this compound in any anticancer attempt either in vitro or in vivo.

On one hand, the development of the new nonguanidine derived NHE1 inhibitors could alleviate some of the detrimental effects of cariporide found in the EXPEDITION trial [116-118]. On the other hand, there are many reasons to think that there can be a significant selectivity of some of these NHE1 inhibitors in cancer (untested so far, at least clinically). In spite that NHE1 is ubiquitous and plays a fundamental role in $\mathrm{pH}$ housekeeping and volume control, it is also well known that in normal tissues the NHE1 is quiescent and is activated only during acidosis or cell shrinkage. Therefore, blocking it will have very little effect on the normal tissues. This should be an advantage to consider and exploit as an important degree of specificity in the anticancer effect of NHE1inhibitors, as it has been known from cell studies since the year $2000[38,44]$.

\section{Towards a new and integral paradigm in human cancer therapeutics \\ Present and future prospects}

The utilization of different PTIs in cancer therapeutics was originally suggested by the group of Pouysségur and our group as a novel approach to the $\mathrm{pH}$-related treatment of malignant tumors because of its potential as a more selective and less toxic approach to therapeutics than conventional chemotherapy $[5,71,129,199]$. We conducted a preliminary clinical trial with the concerted utilization of several PTIs [5,101]. Pouysségur has also proposed the use of PTIs as a valid approach to cancer treatment, advancing that this 'pH-targeted' therapy, perhaps combined with anti-angiogenesis in order to increase hypoxia-mediated acidosis, will synergistically induce the collapse and massive shrinkage of solid tumours [129]. Similarly, from the therapeutic point of view, reverting the Warburg effect by selective intracellular acidification has been advanced as a treatment of cancer [44]. Indeed, in the light of the older and the more recent contributions $[4,28,44-46,59]$ it can now be concluded that counteracting the Warburg effect and its aerobic glycolysis through any therapeutic method directed to selectively induce intracellular acidification in cancer cells and/or reverting proton reversal now appears to represent one and the same phenomenon.

In summary, the most potent and promising amiloride and non-amiloride derivatives, such as cariporide, $\mathrm{Phx}-3$ and compound 9 t, etc. $[37,44,113,198]$ (see Figure 2) need to be included in pre-clinical and clinical trials as an important part of the anticancer armamentarium. That these compounds have not yet reached translational oncology becomes difficult to understand taking into account the massive theoretical background, available preclinical data as well as the results of the molecular, biochemical and metabolic studies already available at the present time. These anticancer compounds can be useful either as antitumoral and chemotherapeutic agents on their own, in the context of preventing and controlling the metastatic process and in any attempts to reverse MDR.

The effects of a targeted therapy are not durable when the therapy is designed to target a single biological molecule. This is because cellular pathways operate like webs with multiple redundancies or alternate routes that may be activated in response to the inhibition of a certain pathway. For this reason, combination and concerted therapies with PTIs will be often needed to effectively treat many tumors screened for pertinent pathway dependence. Incidentally, also in related fields like hyperthermia and radiation, it has also been known for a number of years that to keep the cytosolic $\mathrm{pH}$ at a certain level is fundamental as a survival mechanism, where cellular acidification increases the anticancer potential of both of these methods $[187,188]$, alone or in combination with NHE1 inhibitors. The most potent NHE1 inhibitors could be considered alone as chemotherapeutic agents since they are able to induce intracellular acidification and/or a reverse of the abnormal proton gradient of cancer cells and tissues. It can be advanced that they show a great promise as a new and selective approach to the treatment of a wide array of different malignant tumors and even leukaemias and, hopefully, they will help to overcome the present impasse and flat progress in cancer treatment [101,200]. These strategies have been recently discussed in a review [4] and in a perspective [5] and introduce a real paradigm shift in cancer treatment.

\section{Conclusions}

1) Cell acid-base balance is recognized to be the main parameter to define cellular homeostasis, the life of cells being possible only within a very narrow range 
of $\mathrm{pH}$ (less that one unit). In that context, the $\mathrm{pH}$ of normal cells and cancer cells deviate towards opposite ends of a biological and metabolic spectrum. This energetic abnormality represents the largest difference among normal cellular physiology and cancer pathophysiology.

2) From an etiological and ethiopathogenic perpective, the hydrogen-related dynamics of malignancy have become a new approach to cancer that is helping to reach a better understanding of several, until now disparaged areas of cancer research both at basic and clinical levels, as well as of the intimate nature of the malignant disease. This unifying thermodynamic view permits an integration of different cancer fields, ranging from cell transformation and metabolism, local growth and invasion to neovascularisation and the activation and progression of the metastatic process $(\mathrm{pH}$ centric paradigm).

3) From a therapeutic perspective, the primary aim of this $\mathrm{pH}$-based approach to cancer treatment is to manipulate the selective forces controlling the dysregulated $\mathrm{pH}$ dynamics of all cancer cells and tissues in order to regress tumor growth, control local invasion and deactivate the metastatic potential of malignant tumors within the same integral perspective and paradigm. All available evidence seems to indicate that this would take place regardless of pathological differences, tissue type or genetic origin. This therapeutic approach would also provide much less toxicity than present day treatments, probably more effective therapies than any other chemotherapy known to date and it has real possibilities to become a successful strategy in treating human cancer in general. A pathologically elevated $\mathrm{pH}_{\mathrm{i}}$ and its associated proton reversal (a reversed $\mathrm{pH}$ gradient in cancer cells and tissues $\left(\Delta \mathrm{pH}_{\mathrm{i}}\right.$ to $\left.\Delta \mathrm{pH}_{\mathrm{e}}, \uparrow \mathrm{pH}_{\mathrm{i}} / \downarrow \mathrm{pH}_{\mathrm{e}}\right)$ can be now considered a most specific cancer abnormality and essential hallmark of all kinds of malignant cells and tissues.

4) It can be concluded that aerobic glycolysis or damaged respiration was not the primary cause of cancer, as Warburg incorrectly defended until his death. It now seems more likely that the primary cause of cancer is, precisely, the main cause of the aerobic glycolysis of tumors. And this is that the abnormally high intracellular $\mathrm{pH}$ of cancer cells, mediated by a myriad of etiological factors of many different natures, can very well be the real cause of cancer. Furthermore, this tendency towards cellular alkalinity appears to be an specific and selective characteristic of cancer since it has not been described in any other disease.

5) This hydrogen ion-based perspective has also permitted the better understanding of the Warburg effect, which can now be simply explained by the effects of the concerted action of proton transporters in increasing intracellular $\mathrm{pH}$ and stimulating aerobic glycolysis. In this respect, Otto Warburg and his contemporaries committed an important historical error that has possibly misled several decades of metabolic and biochemical cancer research. The main limitation was probably imposed by the lack of available intracellular $\mathrm{pH}$ measurements before the time of Warburg's death in 1970. The high $\mathrm{pH}_{\mathrm{i}}$ of tumor cells, the Warburg effect and the proton reversal of cancer cells and tissues are likely to represent one and the same phenomenon defined in different ways.

6) Many different environmental and chemical carcinogens have been shown to be cancer-inducing agents because of their potential to stimulate NHE1 activity with the subsequent increase in intracellular $\mathrm{pH}$ and decrease in microenvironmental $\mathrm{pH}$. This cancer-inducing mechanism opens an entire new area in cancer epidemiology looking for generalizations both in detecting and controlling environmental carcinogens.

7) Any attempt to therapeutically induce a selective intracellular acidification using proton transport inhibitors (PTIs) in all cancer cells and tissues would secondarily increase interstitial tumoral $\mathrm{pH}$, thus inhibiting the metastatic process, and represents a rational and firmly based approach to cancer treatment in all stages of development. Further, it has the potential of being selectively exploited in the treatment of many different malignant solid tumours.

8) Cariporide, other potent NHE1 inhibitors of the amiloride series, as well as powerful and selective NHE1 inhibitors of the non-amiloride series, like Phx-3 and compound $9 \mathrm{t}$, have the potential of being highly promising, minimally toxic and truly effective anticancer agents in a wide array of malignant tumours and leukaemias, hopefully representing a new paradigm in cancer therapeutics.

\section{Competing interests}

The authors declare that the research was conducted in the absence of any commercial or financial relationships that could be or become a potential conflict of interests.

\section{Authors' contributions}

SH conceived the review, participated in its design, wrote the first drafts and collaborated in writing and correcting most sections. SJR conceived the review, participated in its design and collaborated in writing and correcting some sections. RAC helped to correct parts of the sections on the role of the NHE1 in oncogenesis and on anticancer potential of NHE inhibitors. JLA and JPO participated in the general script of the review as well as collaborated in the work explained in different figures and tables as well as in collecting and selecting at least half of the list of references. JLA actively participated in discussing and forwarding ideas on the etiology of the Warburg effect. JPO helped to criticize parts of the section on the anticancer potential of NHE inhibitors. $\mathrm{CR}$ main contribution was writing on $\mathrm{pH}, \mathrm{MDR}$ and cancer and $\mathrm{pH}$ and the cell membrane. SF wrote parts of the section on MDR, proton transport inhibitors (PPI), pH and P-gp., and shared his ideas and experience 
on the adjuvant role of PPIs treatment in animal and human cancer. All authors read and approved the final manuscript.

\section{Acknowledgements}

This work was supported by the Mercedes Castresana Foundation, Vitoria, Spain; the Association for Proton Cancer Research and Treatment (APCRT), Madrid, Spain; grant \#11348 of the Italian Association for Cancer Research (I'AIRC), The Italian Ministry of Health, The University of Nottingham UK (NRF4305), the Medical Research Council UK (RA3804), PetPlan Charitable Trust UK (RB3858). We thank Jose Maria Bakero, Virginia Cuadrado, Iñigo Ruiz and the personnel of The Biotechnology Institute (BTI), Vitoria, Spain, for informatic help. The authors want to apologize to all investigators who have significantly contributed to the different research fields reviewed here, past and present, but whose work is not specifically cited in this contribution.

*Note: Stefano Fais is the President and the rest of the authors are members of the International Society of Proton Dynamics in Cancer (ISPDC) (http:// www.ispdc.eu). Salvador Harguindey is President of the Association for Proton Cancer Research and Treatment (APCRT), Madrid, Spain.

\section{Author details}

IInstituto de Biología Clínica y Metabolismo (IBCM), Postas 13-01004, Vitoria, Spain. ${ }^{2}$ School of Veterinary Medicine \& Science, University of Nottingham, Sutton Bonington Campus, LE12 5RD, Sutton Bonington, UK. ${ }^{3}$ Dipartimento del Farmaco, Istituto Superiore di Sanità, Rome, Italy. ${ }^{4}$ Department of Therapeutic Research and Medicines Evaluation, National Institute of Health, Rome, Italy. ${ }^{5}$ Department of Bioscience, Biotechnology and Biopharmaceutics, University of Bari, 70126, Bari, Italy.

Received: 21 May 2013 Accepted: 25 October 2013

Published: 6 November 2013

\section{References}

1. Cardone RA, Casavola V, Reshkin SJ: The role of disturbed pH dynamics and the $\mathrm{Na}+/ \mathrm{H}+$ exchanger in metastasis. Nat Rev Cancer 2005, 5:786-795.

2. Webb BA, Chimenti M, Jacobson MP, Barber DL: Dysregulated pH: a perfect storm for cancer progression. Nat Rev Cancer 2011, 11:671-677.

3. Neri $\mathrm{D}$, Supuran $\mathrm{CT}$ : Interfering with $\mathrm{pH}$ regulation in tumours as a therapeutic strategy. Nat Rev Drug Discov 2011, 10:767-777.

4. Reshkin SJ, Cardone RA, Harguindey S: $\mathrm{Na}+-\mathrm{H}+$ exchanger, $\mathrm{pH}$ regulation and cancer. Recent Pat Anticancer Drug Discov 2013, 8:85-99.

5. Harguindey S, Arranz JL, Wahl ML, Orive G, Reshkin SJ: Proton transport inhibitors as potentially selective anticancer drugs. Anticancer Res 2009, 29:2127-2136

6. Brisson L, Reshkin SJ, Gore J, Roger S: pH regulators in invadosomal functioning: proton delivery for matrix tasting. Eur J Cell Biol 2012, 91:847-860.

7. Brisson L, Gillet L, Calaghan S, Besson P, Le Guennec J, Roger S, Gore J: NaV1. 5 enhances breast cancer cell invasiveness by increasing NHE1dependent H+ efflux in caveolae. Oncogene 2010, 30:2070-2076.

8. Rubin H, Fodge D: Interrelationships of sugar transport and the initiation of DNA synthesisin chick embryo cells. In Control of Proliferation of Animal Cells. Edited by Clarkson B, Baserga R. New York: Cold Spring Harbor Laboratory; 1974:801-816.

9. Perona R, Serrano R: Increased $\mathrm{pH}$ and tumorigenicity of fibroblasts expressing a yeast proton pump. Nature 1988, 334:438-440.

10. Reshkin SJ, Bellizzi A, Caldeira S, Albarani V, Malanchi I, Poignee M, AlunniFabbroni M, Casavola V, Tommasino M: Na+/H+ exchanger-dependent intracellular alkalinization is an early event in malignant transformation and plays an essential role in the development of subsequent transformation-associated phenotypes. FASEB J 2000, 14:2185-2197.

11. Harguindey S, Pedraz JL, Garcia Canero R, Perez de Diego J, Cragoe EJ Jr: Hydrogen ion-dependent oncogenesis and parallel new avenues to cancer prevention and treatment using a $\mathrm{H}(+)$-mediated unifying approach: pH-related and pH-unrelated mechanisms. Crit Rev Oncog 1995, 6:1-33.

12. Shimizu S, Eguchi Y, Kamiike W, Funahashi Y, Mignon A, Lacronique V, Matsuda H, Tsujimoto Y: BCl-2 prevents apoptotic mitochondrial dysfunction by regulating proton flux. Proc Natl Acad Sci U S A 1998, 95:1455-1459.

13. DiGiammarino EL, Lee AS, Cadwell C, Zhang W, Bothner B, Ribeiro RC, Zambetti G, Kriwacki RW: A novel mechanism of tumorigenesis involving pH-dependent destabilization of a mutant p53 tetramer. Nat Struct Biol 2002, 9:12-16.
14. Aravena C, Beltran AR, Cornejo M, Torres V, Diaz ES, Guzman-Gutierrez E, Pardo F, Leiva A, Sobrevia L, Ramirez MA: Potential role of sodium-proton exchangers in the low concentration arsenic trioxide-increased intracellular pH and cell proliferation. PLoS One 2012, 7:e51451.

15. Grinstein S, Rotin D, Mason MJ: Na+/H+ exchange and growth factorinduced cytosolic $\mathrm{pH}$ changes. Role in cellular proliferation. Bioch Biophys Acta 1989, 988:73-97.

16. Wakabayashi S, Fafournoux P, Sardet C, Pouysségur J: The Na+/H+ antiporter cytoplasmic domain mediates growth factor signals and controls "H(+)-sensing". Proc Natl Acad Sci U S A 1992,

89:2424-2428.

17. Sun I, Crane F, Löw H: Bombesin stimulates transplasma-membrane electron transport by Swiss 3 T3 cells. Biochim Biophys Acta (BBA)-Mol Cell Res 1994, 1221:206-210.

18. Eagle $\mathrm{H}$ : Some effects of environmental $\mathrm{pH}$ on cellular metabolism and function. In Control of Proliferation in Animal Cells Cold Spring Harbor Conference on Cell Proliferation. New York: Cold Spring Harbor Laboratory; 1974.

19. Moolenaar WH: Effects of growth factors on intracellular $\mathrm{pH}$ regulation. Annu Rev Plant Physiol Plant Mol Biol 1986, 48:363-376.

20. Chiche J, Ilc K, Laferrière J, Trottier E, Dayan F, Mazure NM, Brahimi-Horn MC, Pouysségur J: Hypoxia-inducible carbonic anhydrase IX and XII promote tumor cell growth by counteracting acidosis through the regulation of the intracellular pH. Cancer Res 2009, 69:358-368.

21. Chiche J, Ricci JE, Pouysségur J: Tumor hypoxia and metabolism - towards novel anticancer approaches. Ann Endocrinol (Paris) 2013,

74(2):111-114

22. L'Allemain G, Paris S, Pouysségur J: Growth factor action and intracellular $\mathrm{pH}$ regulation in fibroblasts. Evidence for a major role of the $\mathrm{Na}+\mathrm{H}+$ antiport. J Biol Chem 1984, 259:5809-5815.

23. Pouysségur J, Franchi A, L'Allemain G, Paris S: Cytoplasmic pH, a key determinant of growth factor-induced DNA synthesis in quiescent fibroblasts. FEBS Lett 1985, 190:115-119.

24. Pouysségur J, Chambard JC, Franchi A, Paris S, Van Obberghen-Schilling E: Growth factor activation of an amiloride-sensitive $\mathrm{Na}+\mathrm{H}+$ exchange system in quiescent fibroblasts: coupling to ribosomal protein $\mathrm{S} 6$ phosphorylation. Proc Natl Acad Sci U S A 1982, 79:3935-3939.

25. Hagag N, Lacal JC, Graber M, Aaronson S, Viola MV: Microinjection of ras p21 induces a rapid rise in intracellular pH. Mol Cell Biol 1987, 7:1984-1988.

26. Doppler W, Jaggi R, Groner B: Induction of v-mos and activated Ha-ras oncogene expression in quiescent NIH 3 T3 cells causes intracellular alkalinisation and cell-cycle progression. Gene 1987, 54:147-153.

27. Harguindey S, Orive G, Luis Pedraz J, Paradiso A, Reshkin SJ: The role of pH dynamics and the $\mathrm{Na}+/ \mathrm{H}+$ antiporter in the etiopathogenesis and treatment of cancer. Two faces of the same coin-one single nature. Biochim Biophys Acta Revs Cancer 2005, 1756:1-24.

28. Lopez-Lazaro M: A new view of carcinogenesis and an alternative approach to cancer therapy. Mol Med 2010, 16:144-153.

29. Harguindey S, Orive G, Cacabelos R, Hevia EM, De Otazu RD, Arranz JL, Anitua $E$ : An integral approach to the etiopathogenesis of human neurodegenerative diseases (HNDDs) and cancer. Possible therapeutic consequences within the frame of the trophic factor withdrawal syndrome (TFWS). Neuropsychiatr Dis Treat 2008, 4:1073-1084.

30. Harguindey S, Reshkin SJ, Orive G, Arranz JL, Anitua E: Growth and trophic factors, $\mathrm{pH}$ and the $\mathrm{Na}+/ \mathrm{H}+$ exchanger in Alzheimer's disease, other neurodegenerative diseases and cancer: new therapeutic possibilities and potential dangers. Curr Alzheimer Res 2007, 4:53-65.

31. Harguindey $\mathrm{S}$, Cragoe EJ Jr: The $\mathrm{Na}+/ \mathrm{H}+$ antiporter in oncology in the light of the spontaneous regression of cancer and cell metabolism. Med Hypotheses 1992, 39:229-237.

32. Harguindey S: Integrating fields of cancer research through pivotal mechanisms and synthetic final pathways: a unifying and creative overview. Med Hypotheses 2002, 58:444-452.

33. Gatenby RA, Gawlinski ET, Gmitro AF, Kaylor B, Gillies RJ: Acid-mediated tumor invasion: a multidisciplinary study. Cancer Res 2006 66:5216-5223.

34. Lauritzen G, Stock CM, Lemaire J, Lund SF, Jensen MF, Damsgaard B, Petersen KS, Wiwel M, Ronnov-Jessen L, Schwab A, Pedersen SF: The $\mathrm{Na}+/ \mathrm{H}+$ exchanger NHE1, but not the $\mathrm{Na}+, \mathrm{HCO} 3(-)$ cotransporter $\mathrm{NBCn} 1$, regulates motility of MCF7 breast cancer cells expressing constitutively active ErbB2. Cancer Lett 2012, 317:172-183. 
35. Bhujwalla ZM, Artemov D, Ballesteros P, Cerdan S, Gillies RJ, Solaiyappan M: Combined vascular and extracellular $\mathrm{pH}$ imaging of solid tumors. NMR Biomed 2002, 15:114-119.

36. Ludwig F, Schwab A, Stock C: The $\mathrm{Na}(+) / \mathrm{H}(+)$-exchanger (NHE1) generates $\mathrm{pH}$ nanodomains at focal adhesions. J Cell Physiol 2012, 228(6):1351-1358.

37. Amith SR, Fliegel $\mathrm{L}$ : Regulation of the $\mathrm{Na}+/ \mathrm{H}+$ Exchanger (NHE1) in Breast Cancer Metastasis. Cancer Res 2013, 73:1259-1264.

38. Rich IN, Worthington-White D, Garden OA, Musk P: Apoptosis of leukemic cells accompanies reduction in intracellular $\mathrm{pH}$ after targeted inhibition of the $\mathrm{Na}(+) / \mathrm{H}(+)$ exchanger. Blood 2000, 95:1427-1434.

39. Porporato PE, Dhup S, Dadhich RK, Copetti T, Sonveaux P: Anticancer targets in the glycolytic metabolism of tumors: a comprehensive review. Front Pharmacol 2011, 2:49.

40. Parks S, Chiche J, Pouysségur J: Disrupting proton dynamics and energy metabolism for cancer therapy. Nat Cancer Revs 2013, 13:611-623.

41. Kaminskas E: The pH-dependence of sugar-transport and glycolysis in cultured Ehrlich ascites-tumour cells. Biochem J 1978, 174:453-459.

42. Relman AS: Metabolic consequences of acid-base disorders. Kidney Int 1972, 1:347-359.

43. Wilhelm G, Schulz J, Hofmann E: pH-dependence of aerobic glycolysis in ehrlich ascites tumour cells. FEBS Lett 1971, 17:158.

44. Nagata H, Che XF, Miyazawa K, Tomoda A, Konishi M, Ubukata H, Tabuchi T: Rapid decrease of intracellular $\mathrm{pH}$ associated with inhibition of $\mathrm{Na}+\mathrm{H}+$ exchanger precedes apoptotic events in the MNK45 and MNK74 gastric cancer cell lines treated with 2-aminophenoxazine-3-one. Oncol Rep 2011, 25:341-346.

45. Che X-F, Zheng C-L, Akiyama S-I, Tomoda A: 2-Aminophenoxazine-3-one and 2-amino-4,4a-dihydro-4a,7-dimethyl-3H-phenoxazine-3-one cause cellular apoptosis by reducing higher intracellular $\mathrm{pH}$ in cancer cells. Proc Japan Acad, Series B Phys Biol Sci 2011, 87:199-213.

46. Harguindey $S$, Henderson ES, Naeher C: Effects of systemic acidification of mice with Sarcoma 180. Cancer Res 1979, 39:4364-4371.

47. Trivedi B, Danforth WH: Effect of $\mathrm{pH}$ on the kinetics of frog muscle phosphofructokinase. J Biol Chem 1966, 241:4110-4114.

48. Gillies RJ: In vivo magnetic resonance spectroscopy in cancer. Annu Rev Biomed Eng 2005, 7:287-326.

49. Gallagher FA, Kettunen MI, Day SE, Hu DE, Ardenkjaer-Larsen JH, Zandt R, Jensen PR, Karlsson M, Golman K, Lerche MH, Brindle KM: Magnetic resonance imaging of $\mathrm{pH}$ in vivo using hyperpolarized 13C-labelled bicarbonate. Nature 2008, 453:940-943.

50. Gerweck LE, Seetharaman K: Cellular pH gradient in tumor versus normal tissue: potential exploitation for the treatment of cancer. Cancer Res 1996, 56:1194-1198.

51. Lutz N, Le Fur Y, Chiche J, Pouysségur J, Cozzone P: Quantitative in-vivo characterization of intracellular and extracellular $\mathrm{pH}$ profiles in heterogeneous tumors: a novel method enabling multiparametric $\mathrm{pH}$ analysis. Cancer Res 2013, 76:4616-4628.

52. Goldblatt $H$, Friedman $L$, Cechner R: On the malignant transformation of cells during prolonged culture under hypoxic conditions in vitro. Biochem Med 1973, 7:241

53. Warburg O: On the origin of cancer cells. Science 1956, 123:309-314.

54. Warburg O, Wind F, Negelein E: The metabolism of tumors in the body. J Gen Physiol 1927, 8:519-530

55. Goldfeder A: Theoretical basis for the acidotic treatment of neoplasia. Am J Surg 1933, 19:307-312.

56. Burk D: A Colloquial Consideration of the Pasteur and Neo-Pasteur Effects. Cold Spring Harb Symp Quant Biol 1939, 7:420-459.

57. Cori CF, Cori GT: The carbohydrate metabolism of tumors. I. The free sugar, lactic acid, and glycogen content of malignant tumors. J Biol Chem 1925, 64:11-22.

58. Eagle $\mathrm{H}$ : The effect of environmental $\mathrm{pH}$ on the growth of normal and malignant cells. J Cell Physiol 1973, 82:1-8.

59. Calderon-Montano JSJ, Robles A, Lopez Lazaro M: Role of the Intracellular $\mathrm{pH}$ in the Metabolic Switch between Oxidative Phosphorylation and Aerobic Glycolysis - Relevance to Cancer. WebmedCentral CANCER 2011, 2:3. WMC001716.

60. Warburg O: The Prime Cause and Prevention of Cancer, The Nobel Lecture, June 1966. Würzburg, Germany: Konrad Triltsch; 1967

61. Warburg O: The Metabolism of Tumors. London: Constable; 1930
62. Weinhouse S: On respiratory impairment in cancer cells. Science 1956, 124:267-269.

63. Gatenby RA, Gillies RJ: Why do cancers have high aerobic glycolysis? Nat Rev Cancer 2004, 4:891-899.

64. Tennant DA, Duran RV, Gottlieb E: Targeting metabolic transformation for cancer therapy. Nat Rev Cancer 2010, 10:267-277.

65. Ristow M: Oxidative metabolism in cancer growth. Curr Opin Clin Nutr Metab Care 2006, 9:339-345.

66. Moreno-Sanchez R, Rodriguez-Enriquez S, Marin-Hernandez A, Saavedra E: Energy metabolism in tumor cells. FEBS J 2007, 274:1393-1418

67. Koppenol WH, Bounds PL, Dang CV: Otto Warburg's contributions to current concepts of cancer metabolism. Nat Rev Cancer 2011 11:325-337.

68. Hsu PP, Sabatini DM: Cancer cell metabolism: Warburg and beyond. Cell 2008, 134:703-707.

69. Burk D, Woods M, Hunter J: On the significance of glucolysis for cancer growth, with special reference to Morris rat hepatomas. $J$ Nat Cancer Inst 1967, 38:839-863.

70. Kritikou E: Metabolism: Warburg effect revisited. Nature Rev Cancer 2008, 8:247-247

71. Kroemer G, Pouysségur J: Tumor cell metabolism: cancer's Achilles' heel. Cancer Cell 2008, 13:472-482.

72. Rietman EA, Friesen DE, Hahnfeldt P, Gatenby R, Hlatky L, Tuszynski JA: An integrated multidisciplinary model describing initiation of cancer and the Warburg hypothesis. Theoret Biol Med Model 2013, 10:39. doi:10.1186/ 1742-4682-1110-1139.

73. Bailey KM, Wojtkowiak JW, Hashim Al, Gillies RJ: Targeting the metabolic microenvironment of tumors. Adv Pharmacol 2012, 65:63-107.

74. Parks S, Chiche J, Pouysségur J: $\mathrm{pH}$ control mechanisms of tumor survival and growth. J Cell Physiol 2011, 226:299-308.

75. Pedersen SF, Stock C: Ion Channels and Transporters in Cancer: Pathophysiology, Regulation, and Clinical Potential. Cancer Res 2013, 73:1658-1661.

76. Izumi H, Torigoe $T$, Ishiguchi $H$, Uramoto H, Yoshida $Y$, Tanabe M, Ise T, Murakami T, Yoshida T, Nomoto M, Kohno K: Cellular pH regulators: potentially promising molecular targets for cancer chemotherapy. Cancer Treat Revs 2003, 29:541-549.

77. Moriyama $\mathrm{Y}$, Nelson $\mathrm{N}$ : Inhibition of vacuolar $\mathrm{H}+-$ ATPases by fusidic acid and suramin. FEBS letters 1988, 234:383.

78. Donowitz M, Tse CM, Fuster D: SLC9/NHE gene family, a plasma membrane and organellar family of $\mathrm{Na}+/ \mathrm{H}+$ exchangers. Mol Aspects Med 2013, 34:236-251

79. Boedtkjer E, Bunch L, Pedersen SF: Physiology, pharmacology and pathophysiology of the $\mathrm{pH}$ regulatory transport proteins NHE1 and NBCn1: similarities, differences, and implications for cancer therapy. Curr Pharm Des 2012, 18:1345-1371.

80. Stock C, Cardone RA, Busco G, Krahling H, Schwab A, Reshkin SJ: Protons extruded by NHE1: digestive or glue? Eur J Cell Biol 2008, 87:591-599.

81. Stock C, Ludwig FT, Schwab A: Is the multifunctional $\mathrm{Na}(+) / \mathrm{H}(+)$ exchanger isoform 1 a potential therapeutic target in cancer? Curr Med Chem 2012, 19:647-660.

82. Rauch C, Blanchard A, Wood E, Dillon E, Whal M, Harguindey S: Multiple Drug Resistance. In Cell Membranes, Cytosolic pH and Drug Transport in Cancer and MDR: Physics, Biochemistry and Molecular Biology. Edited by Meszaros A, Balogh G. New York: Nova; 2009.

83. Daniel C, Bell C, Burton C, Harguindey S, Reshkin SJ, Rauch C: The role of proton dynamics in the development and maintenance of multidrug resistance in cancer. Biochim Biophys Acta 1832, 2013:606-617

84. McLean LA, Roscoe J, Jørgensen NK, Gorin FA, Cala PM: Malignant gliomas display altered $\mathrm{pH}$ regulation by $\mathrm{NHE1}$ compared with nontransformed astrocytes. Am J Physiol-Cell Physiol 2000, 278:C676-C688.

85. Xu K, Mao X, Mehta M, Cui J, Zhang C, Mao F, Xu Y: Elucidation of How Cancer Cells Avoid Acidosis through Comparative Transcriptomic Data Analysis. PloS one 2013, 8:e71177.

86. Harguindey S: Amiloride and its Analogs: Unique Cation Transport Inhibitors. In Use of $\mathrm{Na}+/ \mathrm{H}+$ Antiporter Inhibitors as a Novel Approach to Cancer Treatment. Edited by Cragoe EJ Jr, ThR K, Simchowitz L. New York: VCH Publishers; 1992:317-334 
87. Loo SY, Chang MK, Chua CS, Kumar AP, Pervaiz S, Clement MV: NHE-1: a promising target for novel anti-cancer therapeutics. Curr Pharm Des 2012, 18:1372-1382

88. Huber V, De Milito A, Harguindey S, Reshkin SJ, Wahl ML, Rauch C, Chiesi A, Pouysségur J, Gatenby RA, Rivoltini L, Fais S: Proton dynamics in cancer J Transl Med 2010, 8:57

89. Provost JJ, Wallert MA: Inside out: targeting NHE1 as an intracellular and extracellular regulator of cancer progression. Chem Biol \& Drug Design 2013, 81:85-101.

90. Fliegel $\mathrm{L}$, Fröhlich $\mathrm{O}$ : The $\mathrm{Na}+/ \mathrm{H}+$ exchanger: an update on structure, regulation and cardiac physiology. Biochem J 1993, 296:273.

91. Jankun JS-JE: Molecular basis of specific inhibition of urokinase plasminogen activator by amiloride. Cancer Bioch Biophys 1999, 17:109-123.

92. He B, Deng C, Zhang M, Zou D, Xu M: Reduction of intracellular pH inhibits the expression of VEGF in K562 cells after targeted inhibition of the $\mathrm{Na}+\mathrm{H}+$ exchanger. Leuk Res 2007, 31:507-514.

93. Provost JJ, Rastedt D, Canine J, Ngyuen T, Haak A, Kutz C, Berthelsen N, Slusser A, Anderson K, Dorsam G: Urokinase plasminogen activator receptor induced non-small cell lung cancer invasion and metastasis requires NHE1 transporter expression and transport activity. Cell Oncol 2012, 35:95-110.

94. Kim T-D, Song K-S, Li G, Choi H, Park H-D, Lim K, Hwang B-D, Yoon W-H: Activity and expression of urokinase-type plasminogen activator and matrix metalloproteinases in human colorectal cancer. BMC Cancer 2006 6:211. doi:210.1186/1471-2407-1186-1211.

95. Kellen J, Mirakian A, Kolin A: Antimetastatic effect of amiloride in an animal tumour model. Anticancer Res 1988, 8:1373-1376.

96. Harguindey S, Orive G, Pedraz J, Bello G, Arranz J, Samaniego J: Apparent cure of a cases of metastatic ovarian carcinoma alter chronic treatment with $\mathrm{Na}+-\mathrm{H}+$ antiporter inhibitors. Oncologia Madrid 2002, 25:472-476.

97. Matthews H, Ranson M, Kelso M: Anti-tumour/metastasis effects of the potassium-sparing diuretic amiloride: An orally active anti-cancer drug waiting for its call-of-duty? Intern J Cancer 2011, 129:2051.2061.

98. Alliegro MC, Alliegro MA, Cragoe EJ Jr, Glaser BM: Amiloride inhibition of angiogenesis in vitro. J Exp Zool 1993, 267:245-252.

99. Junior J: Metastatic neuroendocrine carcinoma of the pancreas - case report and literature review. Rev Brasil Oncol 2010, 7(21):24-30.

100. Bellizzi A, Mangia A, Malfettone A, Cardone RA, Simone G, Reshkin SJ, Paradiso $\mathrm{A}: \mathrm{Na}+\mathrm{H}+$ exchanger regulatory factor 1 expression levels in blood and tissue predict breast tumour clinical behaviour. Histopathology 2011, 58:1086-1095

101. Harguindey SMF, Gonzalez Molinillo JM, Chinchilla D, Reshkin SJ, Tomoda A: Further Along a Clinical Protocol Using a Cocktail of PTls in Human Cancer. In ISPDC Abstract Book, 2nd ISPD Meeting, Nice, France, 18-19, 2011; 2011

102. Vairo G, Cocks B, Cragoe E, Hamilton J: Selective suppression of growth factor-induced cell cycle gene expression by $\mathrm{Na}+/ \mathrm{H}+$ antiport inhibitors. J Biol Chem 1992, 267:19043-19046.

103. Hosogi SMH, Nakajima K, Ashihara E, Niisato N, Kusuzaki K, Marunaka Y: An inhibitor of $\mathrm{Na}(+) / \mathrm{H}(+)$ exchanger (NHE), ethyl-isopropyl amiloride (EIPA), diminishes proliferation of MKN28 human gastric cancer cells by decreasing the cytosolic $\mathrm{Cl}(-)$ concentration via DIDS-sensitive pathways. Cell Physiol Biochem 2012, 30:1241-1253.

104. Commisso C, Davidson SM, Soydaner-Azeloglu RG, Parker SJ, Kamphorst JJ, Hackett S, Grabocka E, Nofal M, Drebin JA, Thompson CB: Macropinocytosis of protein is an amino acid supply route in Ras-transformed cells. Nature 2013, 497:633-637.

105. Masereel B, Pochet $L$, Laeckmann D: An overview of inhibitors of $\mathrm{Na}+/ \mathrm{H}+$ exchanger. Europ J Med Chemis 2003, 38:547-554.

106. Harguindey S, Pedraz JL, Canero RG, Katin M: Edelfosine, apoptosis, MDR and $\mathrm{Na}+/ \mathrm{H}+$ exchanger: induction mechanisms and treatment implications. Apoptosis 2000, 5:87-89.

107. Orive G, Reshkin SJ, Harguindey S, Pedraz JL: Hydrogen ion dynamics and the $\mathrm{Na}+/ \mathrm{H}+$ exchanger in cancer angiogenesis and antiangiogenesis. Br J Cancer 2003, 89:1395-1399.

108. Mo X, Chen Q, Li X, Zheng M, Ke D, Deng W, Li G, Jiang J, Wu Z, Wang L: Suppression of NHE1 by small interfering RNA inhibits HIF-1a-induced angiogenesis in vitro via modulation of calpain activity. Microvasc Res 2011, 81:160.

109. Lucien F, Brochu-Gaudreau K, Arsenault D, Harper K, Dubois CM: Hypoxiainduced invadopodia formation involves activation of $\mathrm{NHE}-1$ by the $\mathrm{p} 90$ ribosomal S6 kinase (p90RSK). PloS one 2011, 6:e28851.
110. Jin W, Li Q, Wang J, Chang G, Lin Y, Li H, Wang L, Gao W, Pang T: Na+/H+ exchanger 1 inhibition contributes to K562 leukaemic cell differentiation. Cell Biol Int 2012, 36:739-745.

111. Busco G, Cardone RA, Greco MR, Bellizzi A, Colella M, Antelmi E, Mancini MT, Dell'Aquila ME, Casavola V, Paradiso A, Reshkin SJ: NHE1 promotes invadopodial ECM proteolysis through acidification of the periinvadopodial space. FASEB J 2010, 24:3903-3915.

112. Di Sario A, Bendia E, Omenetti A, De Minicis S, Marzioni M, Kleemann HW, Candelaresi C, Saccomanno S, Alpini G, Benedetti A: Selective inhibition of ion transport mechanisms regulating intracellular $\mathrm{pH}$ reduces proliferation and induces apoptosis in cholangiocarcinoma cells. Dig Liver Dis 2007, 39:60-69.

113. Rupprecht H-J, Vom Dahl J, Terres W, Seyfarth KM, Richardt G, Schulthei $\beta$ H-P, Buerke M, Sheehan FH, Drexler H: Cardioprotective effects of the $\mathrm{Na}+/ \mathrm{H}+$ exchange inhibitor cariporide in patients with acute anterior myocardial infarction undergoing direct PTCA. Circulation 2000, 101:2902-2908.

114. Boyce SW, Bartels C, Bolli R, Chaitman B, Chen JC, Chi E, Jessel A, Kereiakes $D$, Knight J, Thulin L: Impact of sodium-hydrogen exchange inhibition by cariporide on death or myocardial infarction in high-risk CABG surgery patients: results of the CABG surgery cohort of the GUARDIAN study. J Thor Cardiovasc Surg 2003, 126:420-427.

115. Chaitman BR: A Review of the GUARDIAN Trial Results: Clinical Implications and the Significance of Elevated Perioperative CK-MB on 6-Month Survival. J Cardiac Surg 2003, 18:13-20.

116. Mentzer RM Jr, Bartels C, Bolli R, Boyce S, Buckberg GD, Chaitman B, Haverich A, Knight J, Menasché P, Myers ML: Sodium-hydrogen exchange inhibition by cariporide to reduce the risk of ischemic cardiac events in patients undergoing coronary artery bypass grafting: results of the EXPEDITION study. Ann Thor Surg 2008, 85:1261-1270.

117. Zeymer U, Suryapranata H, Monassier JP, Opolski G, Davies J, Rasmanis G, Linssen $\mathrm{G}$, Tebbe $U$, Schroder $\mathrm{R}$, Tiemann $\mathrm{R}$, et al: The $\mathrm{Na}(+) / \mathrm{H}(+)$ exchange inhibitor eniporide as an adjunct to early reperfusion therapy for acute myocardial infarction. Results of the evaluation of the safety and cardioprotective effects of eniporide in acute myocardial infarction (ESCAMI) trial. J Am Coll Cardiol 2001, 38:1644-1650.

118. Theroux P, Chaitman B, Danchin N, Erhardt L, Meinertz T, Schroeder J, Tognoni G, White H, Willerson J, Jessel A: Inhibition of the sodiumhydrogen exchanger with cariporide to prevent myocardial infarction in high-risk ischemic situations: main results of the GUARDIAN trial. Circulation 2000, 102:3032-3038.

119. Avkiran M, Cook A, Cuello F: Targeting $\mathrm{Na}+\mathrm{H}+$ exchanger regulation for cardiac protection: a RSKy approach? Current Opin Pharmacol 2008, 8:133

120. Linz WLHWA, Albus U: Long-term treatment with the NHE1-inhibitor cariporide extends the normal lifespan of Wistar Kyoto rats. Eur Heart $J$ 2001, 22:148.

121. Reshkin SJ, Bellizzi A, Cardone RA, Tommasino M, Casavola V, Paradiso A: Paclitaxel induces apoptosis via protein kinase A- and p38 mitogenactivated protein-dependent inhibition of the $\mathrm{Na}+/ \mathrm{H}+$ exchanger (NHE) NHE isoform 1 in human breast cancer cells. Clin Cancer Res 2003, 9:2366-2373.

122. Baartscheer A, Schumacher CA, Van Borren MM, Belterman CN, Coronel R, Opthof T, Fiolet JW: Chronic inhibition of $\mathrm{Na}+\mathrm{H}+-$ exchanger attenuates cardiac hypertrophy and prevents cellular remodeling in heart failure. Cardiovasc Res 2005, 65:83-92.

123. Kilic A, Velic A, De Windt LJ, Fabritz L, Voss M, Mitko D, Zwiener M, Baba HA Van Eickels M, Schlatter E: Enhanced activity of the myocardial $\mathrm{Na}+/ \mathrm{H}+$ exchanger NHE-1 contributes to cardiac remodeling in atrial natriuretic peptide receptor-deficient mice. Circulation 2005, 112:2307-2317.

124. Humphreys RA, Haist JV, Chakrabarti S, Feng Q, Arnold JMO, Karmazyn M: Orally administered NHE1 inhibitor cariporide reduces acute responses to coronary occlusion and reperfusion. Amer J Physiol-Heart Circulat Physiol 1999, 276:H749-H757.

125. Dhein $\mathrm{S}$, Salameh A: Na+/H+-Exchange Inhibition by Cariporide (Hoe 642): A New Principle in Cardiovascular Medicine. Cardiovasc Drug Revs 1999, 17:134-146.

126. Brahimi-Horn MC, Chiche J, Pouysségur J: Hypoxia and cancer. J Mol Med Berl 2007, 85:1301-1307.

127. Brahimi-Horn C, Pouysségur J: The role of the hypoxia-inducible factor in tumor metabolism growth and invasion. Bull Cancer 2006, 93:E73-80.

128. Lv C, Yang X, Yu B, Ma Q, Liu B, Liu Y: Blocking the $\mathrm{Na}+/ \mathrm{H}+$ exchanger 1 with cariporide (HOE642) reduces the hypoxia-induced invasion of 
human tongue squamous cell carcinoma. Intern J Oral Maxillofac Surg 2012, 41:1206-1210.

129. Pouysségur J, Dayan F, Mazure NM: Hypoxia signalling in cancer and approaches to enforce tumour regression. Nature 2006, 441:437-443.

130. Gao W, Chang G, Wang J, Jin W, Wang L, Lin Y, Li H, Ma L, Li Q, Pang T: Inhibition of $\mathrm{K} 562$ leukemia angiogenesis and growth by selective $\mathrm{Na}+\mathrm{H}+$ exchanger inhibitor cariporide through down-regulation of pro-angiogenesis factor VEGF. Leuk Res 2011, 35:1506-1511.

131. Shi Q, Le X, Wang B, Abbruzzese JL, Xiong Q, He Y, Xie K: Regulation of vascular endothelial growth factor expression by acidosis in human cancer cells. Oncogene 2001, 20:3751.

132. Fukumura D, Xu L, Chen Y, Gohongi T, Seed B, Jain RK: Hypoxia and acidosis independently up-regulate vascular endothelial growth factor transcription in brain tumors in vivo. Cancer Res 2001, 61:6020-6024

133. Xu LFD, Jain RK: Acidic extracellular pH induces vascular endothelial growth factor (VEGF) in human glioblastoma cells via ERK1/2 MAPK signaling pathway: mechanism of low pH-induced VEGF. J Biol Chem 2002, 277(13):11368-11374.

134. Yang XWD, Dong $W$, Song Z, Dou K: Inhibition of $\mathrm{Na}(+) / H(+)$ exchanger 1 by 5 -(N-ethyl-N-isopropyl) amiloride reduces hypoxia-induced hepatocellular carcinoma invasion and motility. Cancer Lett 2010, 2952:198-204.

135. Avery RL, Connor TB, Farazdaghi M: Systemic Amiloride Inhibits Experimentally Induced Neovascularization. Archiv Ophtalmol 1990 108:1474-1476.

136. Aihara K, Hisa H, Sato T, Yoneyama F, Sasamori J, Yamaguchi F, Yoneyama S, Mizuno Y, Takahashi A, Nagai A: Cardioprotective effect of TY-12533, a novel $\mathrm{Na}(+) / \mathrm{H}(+)$ exchange inhibitor, on ischemia/reperfusion injury. Europ J Pharmacol 2000, 404:221-229.

137. Guzman-Perez A, Wester RT, Allen MC, Brown JA, Buchholz AR, Cook ER, Day WW, Hamanaka ES, Kennedy SP, Knight DR: Discovery of zoniporide: A potent and selective sodium-hydrogen exchanger type 1 (NHE-1) inhibitor with high aqueous solubility. Bioorg Medicin Chem Letts 2001, 11:803-807.

138. Fukumoto S, Imamiya E, Kusumoto K, Fujiwara S, Watanabe T, Shiraishi M: Novel, Non-Acylguanidine-Type $\mathrm{Na}+/ \mathrm{H}+$ Exchanger Inhibitors: Synthesis and Pharmacology of 5-Tetrahydroquinolinylidene Aminoguanidine Derivatives. J Med Chem 2002, 45:3009-3021.

139. Martínez-Zaguilán R, Raghunand N, Lynch RM, Bellamy W, Martinez GM, Rojas B, Smith D, Dalton WS, Gillies RJ: pH and drug resistance. I. Functional expression of plasmalemmal V-type $\mathrm{H}+-$ ATPase in drugresistant human breast carcinoma cell lines. Biochem Pharmacol 1999, 57:1037-1046.

140. Luciani F, Spada M, De Milito A, Molinari A, Rivoltini L, Montinaro A, Marra M, Lugini L, Logozzi M, Lozupone F: Effect of proton pump inhibitor pretreatment on resistance of solid tumors to cytotoxic drugs. J Natl Ca Inst 2004, 96:1702-1713.

141. Roepe PD, Wei LY, Cruz J, Carlson D: Lower electrical membrane potential and altered $\mathrm{pHi}$ homeostasis in multidrug-resistant (MDR) cells: further characterization of a series of MDR cell lines expressing different levels of P-glycoprotein. Biochemistry 1993, 32:11042-11056.

142. Miraglia E, Viarisio D, Riganti C, Costamagna C, Ghigo D, Bosia A: Na+/H+ exchanger activity is increased in doxorubicin-resistant human colon cancer cells and its modulation modifies the sensitivity of the cells to doxorubicin. Int J Cancer 2005, 115:924-929.

143. Milosavljevic N, Blanchard A, Wahl ML, Harguindey S, Poet M, Counillon L, Rauch C: Teaching new dogs old tricks: membrane biophysical properties in drug delivery and resistance. Recent Pat Anticancer Drug Discov 2011, 6:334-346

144. Harguindey S, Gillis M: Evolution and cancer: possible relationships to changes in environmental hydrogen ion concentration. J Theor Biol 1980, 86:487-492.

145. Lee H-O, Silva AS, Li Y-S, Slifker M, Gatenby RA, Cheng JD: Evolution of tumor invasiveness: the adaptive tumor microenvironment landscape model. Cancer Res 2011, 71:6327-6337.

146. Alfarouk KO, Ibrahim ME, Gatenby RA, Brown JS: Riparian ecosystems in human cancers. Evolut Applications 2013, 6:46-53.

147. De Milito A, Fais S: Tumor acidity, chemoresistance and proton pump inhibitors. Future Oncol 2005, 1:779-786.
148. Li J, Eastman A: Apoptosis in an Interleukin-2-dependent Cytotoxic T Lymphocyte Cell Line Is Associated with Intracellular Acidification. Role of the $\mathrm{Na} / \mathrm{H}+$ antiport. J Biol Chem 1995, 270:3203-3211.

149. Pérez-Sala D, Collado-Escobar D, Mollinedo F: Intracellular alkalinization suppresses lovastatin-induced apoptosis in $\mathrm{HL}-60$ cells through the inactivation of a pH-dependent endonuclease. J Biol Chem 1995, 270:6235-6242.

150. Reynolds JE, Li J, Craig RW, Eastman A: BCL-2 and MCL-1 expression in Chinese hamster ovary cells inhibits intracellular acidification and apoptosis induced by staurosporine. Exp Cell Res 1996, 225:430-436.

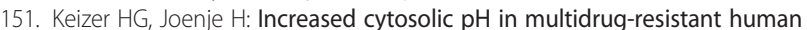
lung tumor cells: effect of verapamil. J Nat Cancer Inst 1989, 81:706-709.

152. Lagadic-Gossmann D, Huc L, Lecureur V: Alterations of intracellular pH homeostasis in apoptosis: origins and roles. Cell Death Differ 2004, 11:953-961.

153. De Milito AFS: Proton pump inhibitors may reduce tumour resistance. Expert Opin Pharmacother 2005, 6:1049-1054.

154. Fais S: Proton pump inhibitor-induced tumour cell death by inhibition of a detoxification mechanism. J Int Med 2010, 267:515-525.

155. Lindner D, Raghavan D: Intra-tumoural extra-cellular $\mathrm{pH}$ : a useful parameter of response to chemotherapy in syngeneic tumour lines. $\mathrm{Br} J$ Cancer 2009, 100:1287-1291.

156. Torigoe T, Izumi $H$, Ise T, Murakami T, Uramoto $H$, Ishiguchi $H$, Yoshida $Y$ Tanabe M, Nomoto M, Kohno K: Vacuolar H+-ATPase: functional mechanisms and potential as a target for cancer chemotherapy. Anticancer Drugs 2002, 13:237-243.

157. Murakami T, Shibuya I, Ise T, Chen ZS, Akiyama S, Nakagawa M, Izumi H, Nakamura T, Matsuo K, Yamada Y: Elevated expression of vacuolar proton pump genes and cellular pH in cisplatin resistance. Intern J Cancer 2001, 93:869-874

158. Paris S, Pouysségur J: Growth factors activate the $\mathrm{Na}+/ \mathrm{H}+$ antiporter in quiescent fibroblasts by increasing its affinity for intracellular $\mathrm{H}+$. J Biol Chem 1984, 259:10989-10994.

159. Thiebaut F, Currier S, Whitaker J, Haugland R, Gottesman M, Pastan I, Willingham M: Activity of the multidrug transporter results in alkalinization of the cytosol: measurement of cytosolic $\mathrm{pH}$ by microinjection of a pH-sensitive dye. J Histochem Cytochemist 1990, 38:685.

160. Boscoboinik D, Gupta R, Epand R: Investigation of the relationship between altered intracellular $\mathrm{pH}$ and multidrug resistance in mammalian cells. Br J Cancer 1990, 61:568.

161. Rauch C, Pluen A: Multi drug resistance-dependent "vacuum cleaner" functionality potentially driven by the interactions between endocytosis, drug size and Pgp-like transporters surface density. Europ Biophs J 2007, 36:121-131.

162. Thews O, Gassnery B, Kelleher DK, Schwerdty G, Gekley M: Impact of Extracellular Acidity on the Activity of P-glycoprotein and the Cytotoxicity of Chemotherapeutic Drugs. Neoplasia 2006, 8:143-152.

163. Rauch C, BA W, Eleanor D, Miriam L, Wahl, Harguindey S: Cell Membranes, Cytosolic pH and Drug Transport in Cancer and MDR: Physics, Biochemistry and Molecular Biology. In Multiple Drug Resistance. Edited by Agoston M, Gusztav B. Hauppauge NY: Nova Science Publishers, Inc; 2009:1-24.

164. Weichert A, Faber S, Jansen H, Scholz W, Lang H: Synthesis of the highly selective $\mathrm{Na}+\mathrm{H}+$ exchange inhibitors cariporide mesilate and (3-methanesulfonyl-4-piperidino-benzoyl) guanidine methanesulfonate. Arzneimittelforschung 1997, 47:1204.

165. Parks SK, Mazure NM, Counillon L, Pouysségur J: Hypoxia promotes tumor cell survival in acidic conditions by preserving ATP levels. J Cell Physio/ 2013, 28(9):1854-1862.

166. L'Allemain G, Franchi A, Cragoe E Jr, Pouysségur J: Blockade of the $\mathrm{Na}+/ \mathrm{H}+$ antiport abolishes growth factor-induced DNA synthesis in fibroblasts. Structure-activity relationships in the amiloride series. J Biol Chem 1984, 259:4313-4319.

167. Fang B, Wang D, Huang M, Yu G, Li H: Hypothesis on the Relationship Between the Change in Intracellular $\mathrm{pH}$ and Incidence of Sporadic Alzheimer's Disease or Vascular Dementia. Internat J Neurosci 2010, 120:591-595.

168. Vincent AM, TenBroeke M, Maiese K: Neuronal intracellular pH directly mediates nitric oxide-induced programmed cell death. J Neurobiol 1999, 40:171-184.

169. Rauch C: Toward a mechanical control of drug delivery. On the relationship between Lipinski's 2 nd rule and cytosolic $\mathrm{pH}$ changes in 
doxorubicin resistance levels in cancer cells: a comparison to published data. Eur Biophys J 2009, 38:829-846.

170. Raghunand N, He X, Van Sluis R, Mahoney B, Baggett B, Taylor C, PaineMurrieta G, Roe D, Bhujwalla Z, Gillies R: Enhancement of chemotherapy by manipulation of tumour pH. Brit J Cancer 1999, 80:1005.

171. lessi E, Marino ML, Lozupone F, Fais S, De Milito A: Tumor acidity and malignancy: novel aspects in the design of anti-tumor therapy. Cancer Ther 2008, 6:55-66.

172. Altan N, Chen Y, Schindler M, Simon SM: Defective acidification in human breast tumor cells and implications for chemotherapy. J Exp Med 1998, 187:1583-1598.

173. Larsen AK, Escargueil AE, Skladanowski A: Resistance mechanisms associated with altered intracellular distribution of anticancer agents. Pharmacol Therap 2000, 85:217-229.

174. Raghunand N, Mahoney BP, Gillies RJ: Tumor acidity, ion trapping and chemotherapeutics: II. pH-dependent partition coefficients predict importance of ion trapping on pharmacokinetics of weakly basic chemotherapeutic agents. Biochem Pharmacol 2003, 66:1219-1229.

175. Raghunand N, Martínez-Zaguilán R, Wright SH, Gillies RJ: pH and drug resistance. II. Turnover of acidic vesicles and resistance to weakly basic chemotherapeutic drugs. Biochem Pharmacol 1999, 57:1047-1058.

176. Rauch C: On the relationship between drug's size, cell membrane mechanical properties and high levels of multi drug resistance: a comparison to published data. Europ Biophys J 2009, 38:537-546.

177. Bell C, Hill C, Burton C, Blanchard A, Shephard F, Rauch C: Importance of the Difference in Surface Pressures of the Cell Membrane in Doxorubicin Resistant Cells That do not Express Pgp and ABCG2. Cell Biochem Biophys 2013, 1:14.

178. De Milito A, lessi E, Logozzi M, Lozupone F, Spada M, Marino ML, Federici C, Perdicchio M, Matarrese P, Lugini L: Proton pump inhibitors induce apoptosis of human B-cell tumors through a caspase-independent mechanism involving reactive oxygen species. Ca Res 2007, 67:5408-5417.

179. De Milito A, Canese R, Marino ML, Borghi M, lero M, Villa A, Venturi G, Lozupone $\mathrm{F}$, lessi E, Logozzi M: pH-dependent antitumor activity of proton pump inhibitors against human melanoma is mediated by inhibition of tumor acidity. Internat I Cancer 2010, 127:207-219.

180. Ruiz-Meana M, Garcia-Dorado D, Pina P, Inserte J, Agulló L, Soler-Soler J: Cariporide preserves mitochondrial proton gradient and delays ATP depletion in cardiomyocytes during ischemic conditions. Am J Physiol-Heart Circulat Physiol 2003, 285:H999-H1006.

181. Marches R, Vitetta ES, Uhr JW: A role for intracellular $\mathrm{pH}$ in membrane lgM-mediated cell death of human B lymphomas. PNAS U S A 2001, 98:3434-3439.

182. Severin T, Müller B, Giese G, Uhl B, Wolf B, Hauschildt S, Kreutz W: pHdependent LAK cell cytotoxicity. Tumor Biol 2009, 15:304-310.

183. Lardner A: The effects of extracellular $\mathrm{pH}$ on immune function. J Leuk Biol 2001, 69:522-530

184. Loeffler D, Juneau $P$, Heppner G: Natural killer-cell activity under conditions reflective of tumor micro-environment. Intern J Cancer 1991, 48:895.

185. Fischer B, Müller B, Fischer K-G, Baur N, Kreutz W: Acidic pH inhibits nonMHC-restricted killer cell functions. Clinic Immunol 2000, 96:252-263.

186. Fischer B, Müller B, Fisch P, Kreutz W: An acidic microenvironment inhibits antitumoral non-major histocompatibility complex-restricted cytotoxicity: implications for cancer immunotherapy. I Immunother 2000, 23:196-207.

187. Haveman J: The $\mathrm{pH}$ of the cytoplasm as an important factor in the survival of in vitro cultured malignant cells after hyperthermia. Effects of carbonylcyanide 3-chlorophenylhydrazone. Eur J Cancer 1979, 15:1281-1288

188. Haveman J: The influence of $\mathrm{pH}$ on the survival after X-irradiation of cultured malignant cells. Effects of carbonylcyanide-3chlorophenylhydrazone. Int J Rad Biol 1980, 37(2):201-205.

189. Choi SYCC, Gout PW, Wang Y: Cancer-generated lactic acid: a regulatory, immunosuppressive metabolite? J Pathol 2013, 230(4):350-355.

190. Shi Y, Kim D, Caldwell M, Sun D: The role of $\mathrm{Na}(+) / h(+)$ exchanger isoform 1 in inflammatory responses: maintaining $\mathrm{H}(+)$ homeostasis of immune cells. Adv Exp Med Biol 2013, 961:411-418.

191. Arig I-H, Wojtkowiak JW, Cohelo Ribeiro ML, Estrella V, Bailey KM, Cornnell HH, Gatenby RA, Gillies RJ: Free Base Lysine Increases Survival and Reduces Metastasis in Prostate Cancer Model. J Cancer Sci Ther 2011, Suppl 1(4):1-7. http://dx.doi.org/10.4172/1948-5956.S1-004.

192. Robey IF, Baggett BK, Kirkpatrick ND, Roe DJ, Dosescu J, Sloane BF, Hashim Al, Morse DL, Raghunand N, Gatenby RA, Gillies RJ: Bicarbonate increases tumor $\mathrm{pH}$ and inhibits spontaneous metastases. Cancer Res 2009, 69:2260-2268

193. Spugnini EP, Baldi A, Buglioni S, Carocci F, De Bazzichini GM, Betti G, Pantaleo I, Menicagli F, Citro G, Fais S: Lansoprazole as a rescue agent in chemoresistant tumors: a phase $\mathrm{I} / \mathrm{Il}$ study in companion animals with spontaneously occurring tumors. J Trans/ Med 2011, 9:221.

194. Robey IF, Martin NK: Bicarbonate and dichloroacetate: evaluating pH altering therapies in a mouse model for metastatic breast cancer. BMC Cancer 2011, 11:235.

195. Sparks R, Pool T, Smith N, Cameron I: Effects of amiloride on tumor growth and intracellular element content of tumor cells in vivo. Ca Res 1983, 43:73-77.

196. Cragoe EJ, Kleyman TR, Simchowitz L: Amiloride and its Analogs: Unique Cation Transport Inhibitors. New York: Wiley-VCH Publishers; 1992.

197. Lorrain J, Briand V, Favennec E, Duval N, Grosset A, Janiak P, Hoornaert C, Cremer G, Latham C, O'Connor SE: Pharmacological profile of SL 59.1227, a novel inhibitor of the sodium/hydrogen exchanger. British J Pharmacol 2000, 131:1188-1194.

198. Atwal KS, O'Neil SV, Ahmad S, Doweyko L, Kirby M, Dorso CR, Chandrasena G, Chen BC, Zhao R, Zahler R: Synthesis and biological activity of 5-aryl-4 (4-(5-methyl-1H-imidazol-4-yl)piperidin-1-yl)pyrimidine analogs as potent, highly selective, and orally bioavailable NHE-1 inhibitors. Bioorg Med Chem Lett 2006, 16:4796-4799.

199. Harguindey S: The pH in the Etiopathogenesis and Treatment of Cancer, Ph D Thesis. Bilbao, Spain: Department of Embriology, The University of the Basque Country (EHU); 1990.

200. Gatenby RA: A change of strategy in the war on cancer. Nature 2009, 459:508-509.

\section{doi:10.1186/1479-5876-11-282}

Cite this article as: Harguindey et al: Cariporide and other new and powerful NHE1 inhibitors as potentially selective anticancer drugs - an integral molecular/biochemical/metabolic/clinical approach after one hundred years of cancer research. Journal of Translational Medicine 2013 11:282

\section{Submit your next manuscript to BioMed Central and take full advantage of:}

- Convenient online submission

- Thorough peer review

- No space constraints or color figure charges

- Immediate publication on acceptance

- Inclusion in PubMed, CAS, Scopus and Google Scholar

- Research which is freely available for redistribution 